\title{
HUKUM PERTAMBANGAN \\ (KEPASTIAN HUKUM TERHADAP INVESTASI SEKTOR PERTAMBANGAN BATUBARA DI DAERAH)
}

\author{
Hartana \\ Mahasiswa Program Doktor Fakultas Hukum UGM \\ Direktur Utama PT. Bumi Kencana Eka Sejahtera \\ Email : hartana_palm@yahoo.com
}

\begin{abstract}
ABSTRAK
Meskipun secara teoritis Indonesia menjadi negara yang potensial sebagai negara tujuan investasi, namun dalam praktik sering terjadi permasalahan yang menimbulkan ketidak pastian hukum. Misalnya kepastian hukum investasi bidang pertambangan. Fenomena ketidakpastian hukum tersebut seperti miss management pengelolaan wilayah pertambangan, tuntutan masyarakat terhadap ketidakadilan dalam pengelolaan pertambangan, penegakan hukum yang lemah dan tidak konsisten, serta berbagai permasalahan lain terkait dengan sistem hukum yang berlaku. Masalah kepastian hukum investasi di bidang pertambangan khususnya terhadap Izin Usaha Pertambangan batubara menurut penulis merupakan suatu persoalan yang menarik dan perlu dilakukan penelitian secara akademis. Dampak ketidakpastian hukum tersebut adalah menurunnya angka investasi pertambangan dalam negeri. Hal ini tampak dalam beberapa tahun terakhir tidak ada investasi asing berskala besar yang masuk ke Indonesia. Oleh karenanya pemerintah berupaya memperbaiki kondisi ini dengan menerbitkan Undang-undang baru yaitu Undang-Undang No. 4 Tahun 2009 tentang Pertambangan Mineral dan Batubara.
\end{abstract}

Kata kunci : Hukum Pertambangan, Kepastian Hukum, Undang-Undang No. 4 Tahun 2009 tentang Pertambangan Mineral dan Batubara

\section{ABSTRACT}

Although theoretically Indonesia becomes a potential country as an investment destination, but in practice the common problems that cause legal uncertainty. Examples of legal certainty for investment in mining. The phenomenon of legal uncertainty like the miss management of the mining area management, the demands of society against the injustice in the management of mining, law enforcement is weak and inconsistent, and various other issues related to the legal system. The problem of legal certainty of investment in the mining sector, especially the coal mining business license according to the authors is an interesting issue and the need to academically research. Impact of legal uncertainty is declining mining investment in the country. This is evident in the last few years there is no large-scale foreign investment into Indonesia. Therefore, the government has attempted to improve these conditions by issuing new Act namely Law No. 4 Year 2009 on Mineral and Coal Mining.

Keywords: Mining Law, Rule of Law, Law No. 4 Year 2009 on Mineral and Coal Mining 


\section{Pendahuluan}

Indonesia adalah salah satu negara dengan kekayaan alam yang sangat melimpah, berbagai kekayaan alam tersebar di berbagai kawasan di Indonesia dan salah satunya yaitu sumber daya di sektor pertambangan. Pasal 33 Undang-Undang Dasar (UUD) 1945 mengamanatkan bahwa bumi dan air serta kekayaan alam yang terkandung di dalamnya dikuasai oleh negara dan dipergunakan untuk sebesar-besar kemakmuran rakyat. Amanat UUD 1945 ini merupakan landasan pembangunan pertambangan untuk memanfaatkan potensi kekayaan sumber daya alam yang dimiliki secara optimal dalam mendukung pembangunan nasional yang berkelanjutan.

Sejak era reformasi, gagasan otonomi daerah terus bergulir, sehingga menyebabkan terjadinya pergeseran paradigma. Paradigma pembangunan yang bersifat sentralistik atau top-down dan hanya terfokus pada pertumbuhan ekonomi bergeser ke paradigma pembangunan yang berlandaskan prinsip dasar demokrasi, kesetaraan, dan keadilan dalam bentuk otonomi daerah.

Pembahasan otonomi daerah dan peraturan pendukungnya tidak terlepas dari sistem politik yang ada. Pakar hukum tata negara Moh. Mahfud MD dalam "Pergulatan Politik dan Hukum Indonesia" melihat bahwa permasalahan konfigurasi hukum dalam suatu rezim akan melatar belakangi semua produk hukum yang dikeluarkannya selama berkuasa, khususnya yang mengatur permasalahan tata negara dan hukum publik. Sebenarnya, UU Pertambangan muncul pada saat konfigurasi politik demokratis yang memiliki karakter responsif atau populistik (www.hukumonline.com). Pada awal pemerintahannya (1966-1971), sistem politik Orde Baru masih demokratis yang memberikan peluang desentralisasi. Namun, sejak 1971 hingga tumbangnya rezim Presiden Soeharto, sistem politiknya otoriter yang memiliki karakter ortodoks. Sejak 1998, konfigurasi politik Indonesia kembali menuju demokratis. Indonesia membuka lembaran baru dengan memberikan kewenangan dan kemungkinan pengembangan inisiatif daerah yang sebesarbesarnya dalam kerangka negara kesatuan.

Dalam sistem negara kesatuan, masalah desentralisasi menjadi amat berpengaruh atas otonomi daerah yang diberlakukan. Pembicaraan desentralisasi akan selalu terkait dengan sentralisasi karena keduanya berkesinambungan. Pasalnya, hampir tidak ada satu negara yang sematamata menganut sentralisasi. Sebaliknya, tidak mungkin hanya dilaksanakan desentralisasi tanpa sentralisasi.

Menurut pakar administrasi negara Bhenyamin Hoessein, desentralisasi sendiri mempunyai dua pengertian. Pertama, desentralisasi merupakan pembentukan daerah otonomi dan penyerahan wewenang tertentu kepadanya oleh pemerintah pusat. Kedua, desentralisasi dapat pula berarti penyerahan wewenang tertentu kepada daerah otonom yang telah dibentuk oleh pemerintah pusat. Definisi kedua inilah yang dipakai sebagai definisi desentralisasi pada Undang - undang (UU) Pemerintahan Daerah. Perwujudan desentralisasi di tingkat daerah adalah otonomi 
daerah. Dengan kata lain, desentralisasi akan selalu terkait dengan otonomi daerah.

UU No. 22 tahun 1999 tentang Pemerintah Daerah dan UU No. 25 tahun 1999 tentang Perimbangan Keuangan antara Pemerintah Pusat dan Daerah memberikan perkembangan mendasar terhadap kebijakan pertambangan nasional. Sentralisasi makin tidak populer dan berganti menjadi desentralisasi. Semangat kedua UU ini ini dalam pendayagunaan sumber daya mineral adalah pendelegasian kewenangan yang lebih besar dalam pengelolaan dan perimbangan yang lebih jelas dan wajar atas penerimaan negara antara pusat dan daerah (www.hukumonline.com).

Otonomi daerah merupakan landasan tambahan bagi penyusunan kebijakan pertambangan nasional, terutama jika dikaitkan dengan perimbangan keuangan pusat dan daerah. Sebelum adanya UU No. 25 tahun 1999, sudah ada iuran pertambangan berupa iuran eksplorasi dan iuran eksploitasi (royalty) dan iuran tetap (land-rent) bumi yang dibagihasilkan ke daerah. Sesuai dengan Peraturan Pemerintah (PP) No. 32 tahun 1969, bagian pemerintah pusat 30\% dan daerah $70 \%$ dari total iuran pertambangan. Bahkan berdasarkan PP No.79 tahun 1992, bagian porsi daerah menjadi $80 \%$. Perinciannya, provinsi $16 \%$ dan daerah tingkat II $64 \%$ (www.hukumonline.com).

Dalam UU No. 25 tahun 1999, pembagiannya tidak jauh berbeda, tetapi royalty dan land-rent dipisahkan. Selain itu, ada perbedaan pendapatan antara provinsi dan kabupaten atau kota. Untuk iuran tetap, pembagiannya $20 \%$ untuk pusat, 16\% untuk kabupaten/ kota provinsi, dan $64 \%$ untuk kabupaten atau kota penghasil. Sementara untuk royalty, pembagiannya $20 \%$ untuk pusat, $16 \%$ untuk kabupaten/ kota provinsi, 32\% untuk kabupaten/ kota penghasil, dan kabupaten/ kota lain dalam provinsi (www.hukumonline.com).

Kewenangan daerah sebenarnya tidak mencakup seluruh sektor dan karenanya tidak dapat mengambil kebijakan sebebasbebasnya. Dalam Pasal 7 UU No 22 tahun 1999 disebutkan bahwa kewenangan daerah mencakup seluruh bidang pemerintahan, kecuali dalam bidang politik luar negeri, pertahanan keamanan, peradilan, moneter/ fiskal, dan agama, yang tetap dipegang oleh pusat. Selain itu, pusat juga tetap berwenang membuat kebijakan perencanaan nasional secara makro, dana perimbangan keuangan, sistem administrasi dan lembaga perekonomian negara, pemberdayaan sumber daya manusia, serta pendayagunaan sumber daya alam.

Otonomi daerah memang memberikan kesempatan bagi daerah untuk menggali potensi bagi kepentingan daerah dan masyarakatnya. Namun, jangan dilupakan otonomi daerah tetap harus diletakkan dalam kerangka kepentingan nasional. Harus juga diperhatikan bahwa investasi pertambangan adalah investasi global, sehingga kepentingan investor lokal maupun asing harus diperhatikan.

$$
\text { Pemerintah daerah (Pemda) }
$$
dapat memposisikan diri sebagai penyelenggara daerah. Pemda bisa memberikan panduan dan kebijakan, sehingga investor tidak lagi kebingungan. Dengan kebijakan yang 
menarik, tentunya diharapkan akan dapat meningkatkan penerimaan bagi daerah setempat. Pemerintah pusat dan asosiasi, dan pakar pertambangan juga diharapkan kiprahnya terhadap berbagai kebijakan yang akan dikeluarkan oleh daerah. Selain untuk kepentingan daerah, hendaknya kebijakan ini masih berpihak bagi kepentingan nasional.

Sejatinya desentralisasi mengakibatkan pembagian wilayah nasional ke dalam wilayah-wilayah yang lebih kecil dan dalam wilayahwilayah tersebut terdapat derajad otonomi tertentu. Masyarakat yang berada dalam wilayah tersebut akan menjalankan pemerintahan sendiri melalui lembaga politik dan birokrasi daerah yang terbentuk. Oleh karena itu, menurut Hoessei (Tri Hayati;2012), desentralisasi merupakan salah satu cara dari apa yang disebut oleh Arthur Maass sebagai "areal division of powers" untuk mendampingi capital division of power (Maddick, 1966:23)

Sebagai konsekuensi desentralisasi dan dekonsentrasi pengalihan kewenangan pusat ke daerah, fungsi pusat akan menjadi pengambil kebijakan dan regulator. Namun, agaknya pelaksanaan otonomi tidak berjalan mulus. Pasalnya, masih banyak daerah yang belum siap melaksanakan otonomi daerah.

Selain itu, ada kendala pelimpahan kewenangan ke provinsi/ kota masih kurang jelas. Apalagi untuk menangani hal-hal baru, khususnya menyangkut investasi asing. Disisi lain, pusat juga masih kurang serius dalam mendukung desentralisasi. Hal ini terlihat dari kurangnya PP yang menunjang otonomi daerah.

Banyak daerah berlomba menjaring investor dan menggali sumber pendapatan dengan mengeluarkan berbagai Peraturan Daerah (Perda). Sayangnya, banyak Perda yang dikeluarkan malah membebani perusahaan-perusahaan pertambangan yang ada di daerahnya, belum lagi adanya pungutan "sumbangan pihak ketiga" yang tak resmi.

Melihat semua fenomena tersebut kemudian timbul rasa khawatir melihat tumpang tindih dan ketidaksinkronan peraturan perundang-undangan. Kini, semakin banyak peraturan yang memuat ancaman pidana bukan saja terhadap orang pribadi, tetapi juga terhadap perusahaan sebagai badan hukum.

Rezim boleh berganti dan undang-undang juga direvisi, tetapi kuncinya tetap pada jaminan kepastian hukum mengingat begitu pentingnya keberadaan investasi ini khususnya di daerah. Investasi merupakan salah satu instrumen dalam sistem perekonomian suatu bangsa yang sangat penting, tidak mengherankan jika di negara maju maupun negara Indonesia berusaha secara optimal untuk menjadi tujuan investasi guna menggerakkan roda perekonomian yang berhubungan langsung dengan sistem produksi, kegiatan perdagangan dan ekspor serta kegiatan ekonomi masyarakat pada umumnya. Ruang lingkup ini tidaklah berlebihan jika dikemukakan bahwa kehadiran investasi merupakan suatu hal yang signifikan dalam pembangunan nasional atau tepatnya dalam menggerakkan roda perekonomian yang dilakukan pemerintah. 
Dengan dasar pemikiran inilah maka perlu adanya suatu kajian khusus yang menjawab setiap pertanyaan mengapa kegiatan investasi selalu berakhir dengan konflik dan ketidakpastian hukum, khususnya investasi pada sector pertambangan. Dari penjelasan Latar Belakang di atas, maka yang menjadi Rumusan Masalah dalam makalah ini adalah sebagai berikut: Bagaimanakah sejarah lahirnya hukum pertambangan di Indonesia?; Bagaimanakah perkembangan hukum pertambangan di Indonesia dari lahirnya hingga kini?; Bagaimanakah perkembangan investasi di tengah dinamika politik otonomi daerah?; Bagaimanakah pengaruh ketidakpastian hukum terhadap investasi di sektor pertambangan?

\section{Pengertian Hukum Pertambangan}

Menurut

Ensiklopedia

Indonesia, yang dimaksud hukum pertambangan adalah hukum yang mengatur tentang penggalian atau pertambangan biji-biji dan mineralmineral dalam tanah. Definisi ini hanya difokuskan pada aktifitas penggalian atau pertambangan bijihbijih. Penggalian atau pertambangan merupakan usahan untuk menggali berbagai potensi-potensi yang terkandung di dalam perut bumi. Di dalam definisi ini juga tidak terlihat bagaimana hubungan antara pemerintah dengan subjek hukum. Padahal untuk menggali bahan tambang itu diperlukan perusahaan atau badan hukum yang mengelolanya (www.fh.unsri.ac.id).

Sedangkan menurut Black law Dictionary (1982: 847), hukum pertambangan adalah :"the act appropriating a mining claim (parcel of land containing precious metal its soil or rock) according to certain established rule". Artinya ketentuan yang khusus yang mengatur hak menambang (bagian dari tanah yang mengandung logam berharga di dalam tanah atau bebatuan) menurut aturan-aturan yang telah ditetapkan.

Sementara itu, Salim HS mendefinisikan Hukum pertambangan adalah: "keseluruhan kaidah hukum yang mengatur kewenangan negara dalam pengelolaan bahan galian (tambang) dan mengatur hubungan hukum antara negara dengan orang dan atau badan hukum dalam pengelolaan dan pemanfaatan bahan galian (tambang)". Kaidah hukum dalam hukum pertambangan dibedakan menjadi dua macam, yaitu kaidah hukum pertambangan tertulis dan tidak tertulis. Hukum pertambangan tertulis merupakan kaidah-kaidah hukum yang terdapat di dalam peraturan perundang-undangan, traktat dan yurisprudensi. Hukum pertambangan tidak tertulis merupakan ketentuan-ketentuan hukum yang hidup dan berkembang dalam masyarakat. Bentuknya tidak tertulis dan sifatnya lokal, artinya hanya berlaku dalam masyarakat setempat.

Menurut Sayuti Thalib, berpendapat bahwa hukum pertambangan dapat digolongkan kepada Hukum Administrasi Negara. Hukum Pertambangan mengatur hubungan mereka yang akan menambang dengan Negara atau Pemerintah

(http://investasibisnis.weebly.com).

Menurut Munir Bustami, secara sederhana mengemukakan bahawa hukum pertambangan adalah serangkaian ketentuan hukum positif yang mengatur segala sesuatu yang 
menyangkut tentang pertambangan, mencakup kelembagaan, kegiatan usaha, serta cara dan proses pelaksanaan kegiatan usahanya. Lebih lanjut Munir Bustami menjelaskan bahwa sumber hukum pertambangan dapat dikategorikan menjadi dua, yaitu (http://hukumpertambangan.wordpr ess.com):

\section{a) Sumber Materil}

Sumber Hukum Pertambangan dalam arti materil adalah sumber hukum yang menentukan isi hukum itu sendiri dan itu tergantung dari sudut pandang mana dilakukan peninjauannya, apakah dari sudut pandang ekonomi, sejarah, sosiologis, filsafat, dan sebagainya. Dapat dikatakan bahwa kebutuhankebutuhan terhadap tambang dalam suatu masyarakat itulah yg menimbulkan isi Hukum Pertambangan.

\section{b) Sumber Formil}

Sumber hukum formil adalah ditemukannya ketentuan hukum dan peraturan perundang-undangan, baik yang tertulis maupun tidak di masyarakat yang berkaitan dengan Pertambangan.

Pertambangan di Indonesia dikuasai oleh negara berdasarkan Pasal 33 UUD 1945. Atas dasar itulah, jika ada pihak lain yang ingin mengelola dan memanfaatkannya haruslah melakukan kerja sama dengan pemerintah karena pemerintahlah yang mempunyai kewenangan untuk mengelola dan memanfaatkannya. Kewenangan negara merupakan kekuasaan yang diberikan oleh hukum kepada negara untuk mengurus, mengatur dan mengawasi pengelolaan bahan galian, sehingga di dalam pengusahaan dan pemanfaatannya dapat meningkatkan kesejahteraan masyarakat. Penguasaan bahan galian tidak hanya menjadi monopoli pemerintah semata-mata, tetapi diberikan hak kepada orang dan/atau badan hukum untuk mengusahakan bahan galian, sehingga hubungan hukum antara negara dengan orang atau badan hukum harus diatur sedemikian rupa agar mereka dapat mengusahakan bahan galian secara optimal.

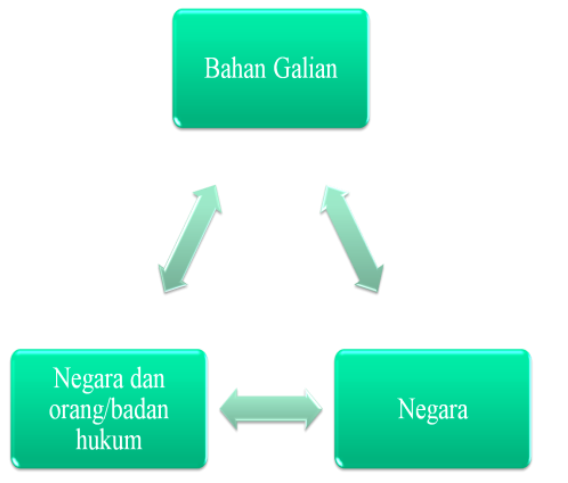

Sementara itu, kerja sama dalam bidang penanaman modal asing dibidang pertambangan diatur dalam Undang-Undang Nomor 4 Tahun 2009 tentang Pertambangan Mineral dan Batubara. Berdasarkan Pasal 112 UU No. 4 Tahun 2009, maka setelah 5 (lima) tahun berproduksi, badan usahapemegang IUP dan IUPK yang sahamnya dimiliki oleh asing wajib melakukan divestasi saham pada Pemerintah, pemerintah daerah, badan usaha milik negara, badan usaha milik daerah, atau badan usaha swasta nasional.

Kerjasama yang berlangsung demikian itu adalah merupakan perbuatan aparatur pemerintah yang berakibat hukum dua pihak. Hal ini disebut sebagai kortverband kontrak sebagai salah satu materi yang dielajari dalam Hukum Tata Negara. 


\section{Objek dan Ruang Lingkup Kajian Hukum Pertambangan}

Apabila mengacu kepada definisi hukum pertambangan di atas, maka akan dapat ditelaah objek dan ruang lingkung dari hukum pertambangan. Objek kajian merupakan sasaran didalam penyelidikan atau pengkajian hukum pertambangan. Objek tersebut dibagi menjadi dua macam, yaitu objek materil dan objek formal.

Objek materil adalah bahan (materil) yang dijadikan sasaran dalam penyelidikannya. Objek materil hukum pertambangan adalah manusia dan bahan galian. Sedangkan objek formal adalah sudut pandang tertentu terhadap objek materilnya. Jadi, objek formal hukum pertambangan adalah mengatur hubungan antara negara dengan bahan galian dan hubungan antara negara dengan orang atau badan hukum dalam pemanfaatan bahan galian.

Kedudukan negara adalah sebagai pemilik bahan galian dan mengatur kepemilikan serta penggunaan bahan galian untuk sebesar-besarnya kemakmuran masyarakat, sehingga negara menguasai bahan galian. Tujuan penguasaan ini adalah agar kekayaan nasional tersebut dimanfaatkan untuk sebesar-besarnya kemakmuran seluruh rakyat Indonesia. Dengan demikian, baik perseorangan, masyarakat maupun para pelaku usaha, sekalipun memiliki hak atas sebidang tanah di permukaan, tidak mempunyai hak menguasai ataupun memiliki bahan galian yang terkandung di bawahnya.

Penguasaan oleh negara diselenggarakan oleh pemerintah sebagai pemegang Izin Usaha Pertambangan. Izin Usaha Pertambangan adalah wewenang yang diberikan oleh negara kepada pemerintah untuk menyelenggarakan kegiatan eksplorasi dan operasi produksi, baik terhadap bahan galian strategis, vital maupun izin galian batuan.

Ruang lingkup kajian hukum pertambangan meliputi pertambangan umum, dan pertambangan minyak dan gas bumi. Pertambangan umum merupakan pertambangan bagian di luar minyak dan gas bumi. Menurut Pasal 34 UU No. 4 Tahun 2009 tentang Pertambangan Mineral dan Batubara, pertambangan umum digolongkan menjadi dua, yaitu pertambangan mineral dan pertambangan batubara. Pertambangan mineral digolongkan menjadi:

a) Pertambangan mineral radioaktif

b) Pertambangan mineral logam

c) Pertambangan mineral bukan logam

d) Pertambangan batuan

Walaupun ruang lingkup kajian hukum pertambangan begitu luas, tapi hanya pertambangan mineral non logam seperti emas, perak dan tembaga serta pertambangan batubara dan pertambangan minyak dan gas bumi yang memiliki nilai komersil yang sangat tinggi dan tidak hanya melibatkan modal dalam negeri, tetapi juga melibatkan modal asing. Modal asing diperlukan untuk membiayai kegiatan pertambangan ini karena Indonesia tidak memiliki modal yang cukup dan sumberdaya manusia yang memadai untuk mengelola sumber daya tambang tersebut. 


\section{Dasar Falsafah Pengusahaan Pertambangan di Indonesia}

Dasar falsafah dari penguasaan dan pengusahaan bahan galian (Minerba) di Indonesia ini, secara mendasar oleh para "Pendiri Negara" dirumuskan dan diletakkan dalam Pasal 33 ayat ( 3 ) UUD 1945 di bawah $B A B$ XIV tentang Kesejahteraan Sosial, yang secara tegas mengamanatkan bahwa : "Bumi dan air dan kekayaan alam yang terkandung didalamnya dikuasai oleh Negara dan dipergunakan untuk sebesar-besar kemakmuran rakyat ". Sesuai Pasal 33 ayat (3) UUD 1945 tersebut, maka sangat jelaslah bahwa hanya Negara saja yang mendapat hak dan kewenangan untuk menguasai "bumi" dan "air" dan "kekayaan alam yang terkandung didalamnya" termasuk mineral dan batubara. Penguasaan mana, mengandung pula amanat kepada Negara, bahwa bumi dan air dan kekayaan alam yang terkandung didalamnya dipergunakan hanya untuk sebesar-besar kemakmuran rakyat.

Lebih lanjut dapat dicermati, bahwa Pasal 33 ayat (3) UUD 1945 yang terlihat sebagai rumusan sederhana. Namun mempunyai makna yang sangat luas dan sangat dalam, yang dirumuskan demi kesejahteraan bagi seluruh rakyat Indonesia. Oleh karena itu mengenai hak penguasan Negara ini, secara cermat ditempatkan khusus dalam BAB XIV tentang Kesejahteraan Sosial yang merupakan hukum dasar untuk kesejahteraan dan kemakmuran rakyat secara nasional. Makna yang sangat dalam ini tercermin dari maksud para Pendiri Negara tersebut, yang secara tegas menetapkan bahwa dalam pemanfaatan sumber daya alam ini. "Bapak-Bapak Bangsa" kita tersebut, sangat memperhatikan tentang kemakmuran rakyat secara nasional dan tidak salah merumuskannya dengan rumusan yang dapat bermakna demi sebesarbesar kemakmuran rakyat setempat, tempat terdapatnya bahan galian termasuk Minerba, sebagai berikut:

a) Bumi dan air dan kekayaan alam yang terkandung didalamnya termasuk Mineral dan batubara, dikuasai oleh Negara. Pengertian "dikuasai oleh Negara" ini, merupakan kreasi dan kecerdikan intelektual dari para pendiri Negara kita tersebut, karena bila dirumuskan dengan kata "dikuasai oleh Pemerintah", maka rumusan tersebut akan bermakna dapat dikuasai baik oleh Pemerintah Pusat maupun oleh Pemerintah Daerah. Sesuai konsep Hukum Administrasi Negara, bahwa Pemerintah dapat berarti Pemerintah Pusat maupun Pemerintah Daerah. Jadi bila dirumuskan dengan kata dikuasai oleh Pemerintah, maka amanat untuk sebesar-besar kemakmuran rakyat. Dapat menjadi hanya sebatas kemakmuran rakyat setempat tempat terdapatnya bahan galian dimaksud.

b) Amanat Konstitusi tersebut, yang hanya memberikan hak penguasaan kepada Negara. Secara yuridis pula tidak bersifat "derivative", artinya tidak dapat dikuasakan kembali kepada siapapun. Baik kepada Lembaga-Lembaga Pemerintah, maupun kepada Pemerintah Daerah, walaupun diberikan suatu dengan landasan Undang-Undang sekalipun. Pada dasarnya tetap akan bersifat batal demi hukum, karena bertentangan dengan UUD 1945 (Hukum Dasar yang tertinggi). 
c) Sedangkan pengertian dari ."dipergunakan untuk sebesarbesar kemakmuran rakyat, adalah bahwa:

1) Pemanfaatan bahan galian, tujuannya hanya satu yaitu untuk sebesar-besar kemakmuran rakyat seluruh Indonesia. Bila yang dimaksudkan tujuannya untuk lebih menekankan pada rakyat setempat (tempat terdapatnya bahan galian tersebut), maka tentunya akan dirumuskan dengan kata "Kemakmuran Masyarakat." dan bukan "kemakmuran rakyat" Inilah kecerdikan dan kecermatan "Founding Father" kita.

2) Hanya Negara yang diamanatkan oleh Konstitusi untuk menyelenggarakan kemakmuran rakyat ini, karena memang hanya Negaralah yang berwenang, berkewajiban dan mampu melaksanakannya secara Nasional.

\section{Pengertian Investasi}

Ada banyak pendapat yang dikemukakan oleh berbagai pihak terhadap pengertian investasi. Secara umum, investasi adalah meliputi pertambahan barang-barang dan jasa dalam masyarakat, seperti pertambahan mesin-mesin baru, pembuatan jalan baru,pembukaan tanah baru dan sebagainya. Investasi juga diartikan sebagai pengeluaran yang di lakukan oleh para pengusaha untuk membeli barang-barang modal dan membina industri- industri.

$$
\text { Istilah investasi atau }
$$
penanaman modal banyak digunakan dalam kegiatan bisnis sehari-hari maupun dalam bahasa perundangundangan, istilah investasi banyak digunakan dalam dunia usaha, maka istilah penanaman modal banyak digunakan dalam perundang-
undangan.
Investasi berasal dari bahasa latin, yaitu investire (memakai), sedangkan dalam bahasa Inggris disebut dengan investment. Dalam berbagai kepustakaan hukum ekonomi atau hukum bisnis, terminologi penanaman modal dapat berarti penanaman modal yang dilakukan secara langsung oleh investor lokal (Domestic investor), investor asing (Foreign Direct Investment) dan penanaman modal yang dilakukan secara tidak langsung oleh pihak asing (Foreign Indirect Investment) melalui pembelian efek lewat Lembaga Pasar Modal (Capital Market).

Dalam perhitungan pendapatan nasional dan satstistik, investasi meliputi hal yang lebih luas lagi. Menurut Sukirno (1994 : 91), dalam perhitungan pendapatan nasional, investasi meliputi hal-hal: "Seluruh nilai pembelian pengusaha atas barang-barang modal dan pembelanjaan untuk mendirikan industri-industri, pengeluaran masyarakat untuk mendirikan rumah-rumah dan tempat tinggal, pertambahan dalam nilai stok barang-barang berupa bahan mentah, barang yang belum selesai di proses dan barang jadi.

Dalam kaitannya dengan perusahaan dimana perusahan melakukan investasi guna mendapatkan profit yang sebesarbesarnya, di mana dana investasi tersebut salah satunya bersumber dari dana masyarakat yang di tabung pada lembaga-lembaga keuangan, maka Deliarnov mengemukakan bahwa "investasi merupakan pengeluaran perusahaan secara keseluruhan yang mencakup 
pengeluaran untuk membeli bahan baku/ material, mesin-mesin dan peralatan pabrik serta semua modal lain yang di perlukan dalam proses produksi. Pengeluaran untuk keperluan bangunan kantor, pabrik tempat tinggal karyawan dan bangunan kontruksi lainnya. Perubahan nilai stok atau barang cadangan sebagai akibat dari perubahan jumlah dan harga".

Menurut Dj. A Simarmata, dalam bukunya mendefinisikan investasi yang lebih luas yang di kaitkan dengan perkembangan pasar modal sekarang yakni investasi adalah setiap kegiatan yang hendak menanamkan uang dengan aman (http://www.ramdri.com.).

Menurut Ikatan Akuntansi Indonesia dalam PSAK, investasi adalah suatu aktiva yang digunakan perusahaan untuk pertumbuhan kekayaan (accreation of wealth) melalui distribusi hasil investasi (seperti: bunga, royalti, deviden dan uang sewa), untuk apresiasi nilai investasi atau untuk manfaat lain bagi perusahaan yang berinvestasi seperti manfaat yang diperoleh melalui hubungan perdagangan.

Menurut James C Van Horn (1981), investasi adalah kegiatan yang dilangsungkan dengan memanfaatkan kas pada masa sekarang ini, dengan tujuan untuk menghasilkan barang di masa yang akan datang.

Sedangkan menurut Henry Simamora (2000:438), investasi adalah suatu aktiva yang digunakan oleh perusahaan untuk pertumbuhan kekayaannya melalui distribusi hasil investasi (seperti pedapatan bunga, royalty, deviden, pendapatan sewa dan lain - lain), untuk apresiasi nilai investasi, atau untuk manfaat lain bagi perusahaan yang berinvestasi, seperti manfaat yang diperoleh melalui hubungan dagang.

Sementara itu, menurut Fitz Gerald (1978), investasi adalah yaitu aktivitas yang berkaitan dengan usaha penarikan sumber-sumber yang dipakai untuk mengadakan modal barang pada saat sekarang ini. Barang modal tersebut akan menghasilkan aliran produk baru di masa yang akan datang. Fitz Gerald juga mengungkapkan bahwa investasi yaitu aktivitas yang berkaitan dengan usaha penarikan sumber-sumber untuk dipakai mengadakan barang. Dari modal tersebut akan dihasilkan aliran produk baru di masa yang akan datang.

Dalam definisi ini investasi dikonstruksikan sebagai sebuah kegiatan untuk:

a. Penarikan sumber dana yang digunakan untuk pembelian barang modal

b. Barang modal itu akan dihasilkan produk baru

Definisi lain dikemukakan oleh Kamarudin Ahmad, yang mangartikan investasi adalah "menempatkan uang atau dana dengan harapan untuk memperoleh tambahan atau keuntungan tertentu atas uang atau dana tersebut". Dalam definisi investasi menurut Kamarudin Ahmad, investasi difokuskan pada penempatan uang atau dana. Tujuannya adalah untuk memperolah keuntungan.

Dalam Undang-Undang Nomor 25 Tahun 2007 Tentang Penanaman Modal

(UUPM) dikemukakan "penanaman modal adalah segala bentuk kegiatan penanaman modal asing untuk melakukan usaha di wilayah Negara 
Republik Indonesia". Penanam modal dapat berupa perseorangan atau badan usaha yang melakukan penanaman modal yang dapat berupa penanam modal dalam negeri dan penanam modal asing.

Menurut Sunariyah (2003:4), "investasi adalah penanaman modal untuk satu atau lebih aktiva yang dimiliki dan biasanya berjangka waktu lama dengan harapan mendapatkan keuntungan di masamasa yang akan datang. Dewasa ini banyak negara-negara yang melakukan kebijaksanaan yang bertujuan untuk meningkatkan investasi baik domestik ataupun modal asing. Hal ini dilakukan oleh pemerintah sebab kegiatan investasi akan mendorong pula kegiatan ekonomi suatu negara, penyerapan tenaga kerja, peningkatan output yang dihasilkan, penghematan devisa atau bahkan penambahan devisa.

Menurut Husnan (1996:5) menyatakan bahwa "proyek investasi merupakan suatu rencana untuk menginvestasikan sumber-sumber daya, baik proyek raksasa ataupun proyek kecil untuk memperoleh manfaat pada masa yang akan datang. "Pada umumnya manfaat ini dalam bentuk nilai uang. Sedang modal, bisa saja berbentuk bukan uang, misalnya tanah, mesin, bangunan dan lain-lain.

Menurut Kasmir dan Jakfar (2012) investasi dapat diartikan sebagai penanaman modal dalam suatu kegiatan yang memiliki jangka waktu relatif panjang dalam berbagai bidang usaha. Penanaman modal yang ditanamkan dalam arti sempit berupa proyek tertentu baik bersifat fisik atau pun non fisik, seperti proyek pendirian pabrik, jalan, jembatan, pembangunan gedung dan proyek penelitian, dan pengembangan.

Menurut Downes dan Goodman, investasi adalah investasi keuangan dimana seorang investor menanamkan uangnya dalam bentuk usaha dalamwaktu tertentu dari setiap orang yang ingin memperoleh laba dari keberhasilan pekerjaannya.

Menurut Tandelilin, investasi adalah komitmen atas sejumlahdana lainnya yang dilakukan pada saat ini dengan tujuan untuk memperolehkeuntungan di masa yang akan datang.

Menurut M. Suparmoko (1994 :79-80), investasi adalah pengeluaran yang ditujukan untuk menambah atau mempertahankan persediaan kapital (capital stock). Persediaan kapital ini terdiri dari pabrik-pabrik, mesin-mesin kantor, barang tahan lama lainnya yang dipakai dalam proses produksi. Termasuk dalam persediaan kapitaladalah rumah-rumah dan persediaan barang-barang yang belum dijual atau dipakai pada tahun yang bersangkutan (inventory). Jadi investasi adalah pengeluaran yang menambah persediaan kapital.

Menurut Martono dan D. Agus Marjito (2002:138), menyatakan bahwa "investasi merupakan penanaman dana yang dilakukan oleh suatu perusahaan kedalam suatu asset (aktiva) dengan harapan memperoleh pendapatan dimasa yang akan datang."

Menurut Sutojo investasi adalah usaha menanamkan faktor-faktor produksi langka dalam proyek tertentu, baik yang bersifat baru sama sekali atau perluasan proyek atau pabrik yang sudah ada untuk memperoleh manfaat 
keuangan dan/atau non keuangan yang layak dikemudian hari.

Sedangkan menurut Haming dan Basalamah investasi merupakan pengeluaran pada saat sekarang untuk membeli aktiva riil (tanah, rumah, mobil, dsb) atau aktiva keuangan dengan tujuan untuk mendapatkan penghasilan yang lebih besar dimasa yang akan datang, selanjutnya dikatakan investasi adalah aktivitas yang berkaitan dengan usaha penarikan sumbersumber (dana) yangdipakai untuk mengadakan barang modal pada saat sekarang, dengan barangmodal itu akan dihasilkan aliran produk baru di masa yang akan datang.

Menurut Sadono Sukirno (1997 : 107), investasi dapat diartikan sebagai pengeluaran atau pembelanjaan penanam-penanam modal atau perusahaan untuk membeli barang-barang modal dan perlengkapan-perlengkapan produksi untuk menambah kemampuan memproduksi barang-barang dan jasa-jasa yang tersedia dalam perekonomian.

Dari berbagai pendapat tentang definisi mengenai investasi, penulis berpendapat terdapat satu kesamaan arti yaitu investasi merupakan suatu pengeluaran sejumlah dana dari investor atau pengusaha guna membiayai kegitan produksi untuk mendapatkan profit di masa sekarang dan dimasa yang akan datang.

\section{Pembahasan}

\section{Sejarah kegiatan Usaha Pertambangan di Indonesia}

Sejarah kegiatan usaha dan hukum pertambangan di Indonesia menurut Sutaryo Sigit (1996), secara resmi dapat ditemukan dalam catatan-catatan kegiatan para geologist Belanda yang pernah melakukan survey di negeri ini. Antara lain TerBraake (1944) dan $R$.W Van Bemmelen (1949), serta berbagai laporan tahunan Dinas Pertambangan Hindia Belanda ("Jaarverslag Dienst Van Den Mijn Bow").

Pada masa Pemerintahan Hindia Belanda sudah ada keterlibatan swasta, sehingga Pemerintah Hindia Belanda membentuk suatu Komisi Khusus (1950) untuk mempelajarai dan menyusun bentuk pengaturan usaha pertambangan. Komisi ini berhasil menyusun sebuah peraturan pertambangan (mijnreglement) yang pertama. Peraturan ini memungkinkan pemberian hak atau konsesi penambangan kepada swasta warga Negara Belanda, tetapi masih terbatas untuk daerah-daerah di luar Pulau Jawa (Abrar Saleng;2004). Berdasarkan catatan-catatan tersebut terkesan bahwa seakan-akan kegiatan usaha pertambangan di Indonesia ini, baru dimulai sejak tahun 1899. Yaitu tahun diundangkannya Indische Mijn Wet, Stb. Tahun 1899 No.214.

Akan tetapi pada kenyataannya kegiatan usaha pertambangan di negeri ini, sudah terlihat jejak peninggalannya sejak zaman keemasan kerajaan Hindu Sriwijaya dan masa kejayaan Majapahit. Hal tersebut ditandai dengan banyaknya pengrajin perkakas logam pada saat itu, yang dikenal sebagai jaman perunggu. Bahkan sebenarnya kegiatan pertambangan di negeri ini, telah berlangsung jauh sebelum kerajaan-kerajaan Hindu tersebut muncul. Dimana sejak awal sejarah bangsa ini, Nenek moyang kita sudah terkenal sebagai pengrajin perkakas 
logam yang handal seperti: Kapak, Tombak, Parang, Keris, Badik, Mandau, Arit dan Cangkul. Masa itu dikenal dalam sejarah sebagai zaman Perunggu. Adanya zaman Perunggu ini tentunya tidak lepas dari kemampuan nenek moyang kita itu, untuk menambang dan mengolah bijih-bijih logam yang ada untuk dijadikan logam-logam dasar sebagai bahan pokok pembuatan perkakas dan peralatan kehidupannya. Pada dasarnya pengolahan bijih-bijih logam yang dilakukan oleh nenek moyang kita ini, adalah suatu pekerjaan proses metalurgi walaupun dalam bentuk yang sangat sederhana (Tri Hayati;72).

$$
\text { Jauh sebelum Belanda }
$$

menjejakkan kakinya di Bumi Nusantara, pelaut portugis lebih dulu sampai di Negeri kaya rempah ini. Bahkan pada 1511, Portugis dibawah Alfonso d'Albuquerque telah menguasai Malaka. Portugis juga telah mampu membuat peta jalur pelayaran menuju Nusantara, tetapi masih dirahasiakan. Pada 1595 ada seseorang bernama Jan Huygen van Linschoten menerbitkan sebuah buku berjudul Itinerario naer Oost ofte Portugaels Indien yang berisi peta panduan dan deskripsi jalur pelayaran Portugis sampai ke Nusantara. Atas dasar itulah pada tahun yang sama pengusaha Belanda mengirim ekspedisi Hindia Timur yang dipimpin oleh Cornelis de Houtman untuk melakukan perdagangan

Pada awalnya Belanda datang di bumi Nusantara karena tertarik akan rempah-rempah khas seperti pala dan lada yang melimpah di negri ini. Belanda juga mengeksploitasi kesuburan dari tanah Nusantara dengan membuka perkebunan aneka komoditas dengan menerapkan sistem tanam paksa yang sangat menyengsarakan penduduk pribumi. Selain itu, Belanda juga melirik kekayaan mineral khususnya emas. Jejak kegiatan penambangan yang dilakukan Belanda selama berkuasa di Indonesia masih dapat dijumpai mulai dari Sumatera, Jawa, Kalimantan, dam Sulawesi (www.mineraltambang.com).

Pada saat itu, Nusantara sudah terkenal akan kekayaan emasnya. Emas sebagai salah satu komoditas tambang sudah dikenal dan diusahakan di Nusantara sejak lebih dari seribu tahun yang lalu. Selain situs tambang, banyak artefak yang ditemukan para arkeolog yang terbuat dari emas, baik berupa mahkota, perhiasan, perlengkapan peribadatan, hingga peralatan seharihari. Legenda atau mitos dengan emas menjadi bagian dari kisahnya, masih dituturkan hingga sekarang. Secara empiris hal tersebut membuktikan bahwa sejak dahulu, beberapa daerah di negri ini pernah menjadi pusat penambangan emas, pengrajin emas, hingga perdagangan emas.

Sejarah pertambangan dan energi di Indonesia dimulai dengan kegiatan pertambangan yang dilakukan secara tradisional oleh penduduk dengan seizin penguasa setempat. seperti, Raja, ataupun Sultan. Pada tahun 1602 Pemerintah Belanda membentuk VOC, selain menjual rempah-rempah juga mulai melakukan perdagangan hasil pertambangan, pada tahun 1652 mulailah dilakukan penyelidikan berbagai aspek ilmu kealaman oleh para ilmuwan dari Eropa. Pada tahun 1850 Pemerintah Hindia Belanda membentuk Dienst van het Mijnwezen 
(Mijnwezenn - Dinas Pertambangan) yang berkedudukan di Batavia (sekarang Jakarta) untuk lebih mengoptimalkan penyelidikan geologi dan pertambangan menjadi lebih terarah.

Berdasarkan catatan sejarah tersebut, maka dapat diketahui pula bahwa penambangan emas, tembaga, dan besi di Pulau Jawa dan Pulau Sumatera secara komersial sudah dimulai menjelang tahun 700 Masehi. Maka pada masa itu Pulau Sumatera dikenal sebagai Swarna Dwipa (Pulau Emas ) dan Pulau Jawa dikenal sebagai Jawa Dwipa (Pulau Beras). Selanjutnya sejak Belanda datang pada tahun 1602 Masehi, sebagai kelompok pedagang yang tergabung dalam Verenigde Ooze Indische Company dan terkenal dengan sebutan VOC, maka mulailah era baru dalam kegiatan pengusahaan pertambangan di Indonesia yang lebih modern dengan sekala yang besar pula. Pada masa ini mulailah Timah di tambang di Pulau Bangka pada tahun 1710, di Pulau Belitung pada tahun 1851, dan di Pulau Singkep pada tahun 1887. Sedangkan Batubara mulai di tambang di Pulau Jawa pada tahun 1854, Aspal di Pulau Buton pada tahun 1909, Nikel di Pulau Sulawesi pada tahun 1916 dan Bauksit di P. Intan pada tahun 1925 (www.esdm.go.id).

Menjelang tahun 1920, sesuai dengan rencana Pemerintah Hindia Belanda menjadikan Bandung sebagai ibukota Hindia Belanda, maka dilakukan persiapan untuk memindahkan kantor Mijnwezen ke Bandung. Pada perjalanannua Mijnwezen berada dibawah naungan Departement Burgerlijke Openbare Werken (Departemen Pekerjaan
Umum) dan berkantor di Gedung Sate (www.esdm.go.id).

Pada tahun 1922, lembaga Mijnwezen ini berganti nama menjadi Dienst van den Mijnbouw. Pada Tahun 1928 Pemerintah Hindia Belanda mulai membangun gedung Geologisch Laboratorium yang terletak di jalan Wilhelmina Boulevard untuk kantor Dienst van den Mijnbouw dan diresmikan pada tanggal 16 Mei 1929. Selama Perang Dunia ke II, gedung ini kerap dipergunakan sebagai tempat pendidikan Assistent Geologen Cursus (Kursus Asisten Geologi), dengan peserta hanya beberapa orang saja diantaranya, Raden Soenoe Soemosoesastro dan Arie Frederik Lasut. Dua orang peserta pribumi itulah yang kemudian menjadi pegawai menengah pertama di kantor Mijnbouw sejak tahun 1941 yang dikemudian hari menjadi tokoh perjuangan dalam membangun kelembagaaan tambang dan geologi nasional (www.esdm.go.id).

Pada masa penjajahan Jepang (1942-1945), Mijnbouw dengan segala sarana dan dokumennya diambilalih oleh Jepang dan namanya diganti menjadi Chisitsu Chosasho. Kantor Chisitsu Chosasho tidak dapat berbuat banyak karena ketiadaan tenaga ahli dan anggaran. Tenaga ahli Belanda pada awalnya masih dipertahankan tetapi kemudian diinternir, kecuali mereka yang diperlukan oleh Jepang (www.esdm.go.id).

Proklamasi Kernerdekaan Indonesia pada tanggal 17 Agustus 1945 mengantarkan perubahan yang sangat besar di segala bidang, termasuk bidang pertambangan. Setelah disiarkan melalui radio, berita tentang proklamasi dapat diterima secara luas oleh masyarakat 
di seluruh Indonesia. Pegawai pribumi di kantor Chisitsu Chosasho yang sebagian besar masih muda, menerima berita itu dan mereka langsung mempersiapkan diri untuk mengambil Iangkah yang diperlukan (www.esdm.go.id).

Pada awal kemerdekaan, kegiatan pengelolaan pertambangan dan energi menghadapi berbagai kesulitan dan tidak banyak yang dapat diperbuat di bidang usaha ini. Di beberapa tempat, fasilitas pertambangan dan energi dibumi hanguskan agar tidak dapat dipakai oleh kekuatan kolonial. Walaupun demikian, kegiatan di bidang ini tidak dapat dikatakan lumpuh sama sekali (www.esdm.go.id).

$\begin{array}{lcr}\quad \text { Pada masa itu, } & \text { bangsa } \\ \text { Indonesia telah } & \text { mampu } \\ \text { memproduksi } & \text { minyak } & \text { bumi }\end{array}$ sebanyak 6.000 barel per hari, batubara 37.000 ton per tahun, timah 1.050 ton per tahun, serta memproduksi tenaga listrik yang berasal dari pembangkit tenaga listrik perusahaan swasta yang dinasionalisasi dan milik pemerintah sebesar 504.000 MWh. Penyediaan listrik ini dilakukan oleh perusahaan listrik dan gas yang diambil alih dari pemerintah pendudukan Jepang dan selanjutnya diberi nama Jawatan Listrik dan Gas. Kemudian dengan Penetapan Pemerintah Nomor 1/S.D. Tahun 1945, jawatan ini dimasukkan ke dalam struktur Departemen Pekerjaan Umum. Penting untuk dicatat pula adalah berhasilnya upaya penyelamatan dokumen dan peta kekayaan tambang dan mineral Indonesia, yang kemudian menjadi modal utama dalam pencarian kekayaan mineral serta membangun sektor pertambangan dan energi (www.bappenas.go.id).

Setelah pengakuan kedaulatan pada bulan Desember 1949, semua saham perusahaan minyak milik pemerintah kolonial Belanda dialihkan ke Pemerintah Indonesia. Kegiatan di sektor pertambangan dan energi mulai dilakukan kembali dengan merehabilitasi dan mengelola instalasi-instalasi yang dibangun di jaman penjajahan. Namun, kegiatan eksplorasi dan produksi masih sangat terbatas. Kegiatan penyelidikan geologi, eksplorasi dan hasil pertambangan dalam periode ini belum menunjukkan perkembangan yang berarti (www.bappenas.go.id).

Pada tahun 1958, Pemerintah Indonesia mengeluarkan UndangUndang Nomor 86 Tahun 1958 tentang nasionalisasi perusahaan pertambangan milik Belanda. Hal ini merupakan peristiwa penting bagi pembangunan pertambangan selanjutnya. Pada tahun 1959, semua perusahaan Belanda antara lain perusahaan tambang batubara, timah, emas, dan bauksit ditetapkan pengelolaannya oleh Biro Urusan Perusahaan Tambang Negara (BUPTAN). Konsesi-konsesi pertambangan sejak perang kemerdekaan yang tidak diusahakan lagi atau baru diusahakan dalam tahap permulaan dikenakan pembatalan hak-hak pertambangan sesuai dengan ketentuan UndangUndang Nomor 10 Tahun 1959. Daerah-daerah bekas konsesi yang dibatalkan hanya dapat diusahakan oleh perusahaan negara atau perusahaan milik daerah Swatantra.

Produksi batubara makin berkembang sebagai energi pengganti minyak bumi. Hal ini 
ditandai dengan adanya eksploitasi dan dikembangkannya tambang tembaga dan emas secara besarbesaran di Irian Jaya dan dibangunnya pabrik peleburan nikel di Soroako, Sulawesi Selatan dan di Pomalaa, Sulawesi Tenggara. Produksi timah juga dapat ditingkatkan, sehingga Indonesia merupakan salah satu pengekspor timah terbesar di dunia. Beberapa produksi bahan tambang lainnya seperti perak, bauksit, fosfat, dan bahan galian industri lainnya yang semula hanya dipakai untuk memenuhi kebutuhan dalam negeri sudah mulai diekspor. Hal yang demikian itu mendorong pemerintah untuk menetapkan kebijaksanaan energi nasional pada tahun 1980. Produksi batubara meningkat pesat dari hanya 159,9 ribu ton pada awal Pembangunan Jangpa Panjang Pertama (PJP I) menjadi 28,5 juta ton pada akhir PJP I. Ekspor batubara yang dimulai pada akhir Repelita II dengan jumlah 27,3 ribu ton telah meningkat menjadi 19 juta ton pada akhir PJP I dan menempatkan Indonesia sebagai salah satu pengekspor batubara terkemuka di dunia. Menjelang akhir PJP I, penggunaan briket batubara untuk keperluan rumah tangga dan industri kecil sudah mulai dimasyarakatkan, untuk menggantikan minyak tanah dan BBM lainnya.

Peningkatan pembangunan di sektor pertambangan dan energi tidak terlepas dari dikembangkan dan diselesaikannya sejumlah peta dan informasi geologi mengenai keberadaan sumber mineral dan energi Indonesia. Pemetaan dan penyelidikan geologi juga telah berhasil meningkatkan kesiapsiagaan dalam rangka mitigasi dan penanggulangan bencana alam geologi, serta menjadi bahan bagi penataan ruang. Untuk itu selama PJP I antara lain telah diselesaikan 90 persen peta geologi bersistem; 83 persen peta daerah bahaya gunung api; 46 persen pemetaan batubara dan gambut; serta mulai dilakukannya pemetaan geologi dasar laut dan pemboran pengujian panas bumi.

Dengan berlandaskan hasil pembangunan yang telah dicapai dalam PJP I, maka pembangunan pertambangan dan energi akan dilanjutkan dan ditingkatkan dalam PJP II, diawali dengan Repelita VI. Sasaran pembangunan pertambangan dalam Repelita VI adalah meningkatnya produksi dan diversifikasi hasil tambang untuk memenuhi kebutuhan bahan baku industri dan sumber energi primer, serta meningkatnya ekspor dan pemenuhan keperluan masyarakat lainnya; terwujudnya sistem pengelolaan pertambangan yang efisien dan produktif yang didukung oleh kemampuan penguasaan teknologi dan sumber daya manusia yang berkualitas; meningkatnya peran serta masyarakat dalam usaha pertambangan, terutama melalui wadah koperasi; meluasnya pembangunan pertambangan di daerah guna mendukung pengembangan wilayah, terutama kawasan timur Indonesia; dan tersedianya pelayanan informasi geologi dan sumber daya mineral yang andal, baik untuk eksplorasi lanjut, penataan ruang maupun mitigasi bencana alam geologis.

Sasaran pembangunan pertambangan di bidang geologi dan sumber daya mineral dalam 
Repelita VI, antara lain adalah penyelesaian peta geologi dan daerah bahaya gunung api Indonesia, yang terdiri atas pemetaan dan penyelidikan geologi dan geofisika sejumlah 104 peta; pemetaan dan penyelidikan geologi kelautan sejumlah 25 lembar peta dan 30 lokasi; inventarisasi dan pemetaan serta eksplorasi sumber daya mineral sejumlah 55 lembar peta dan 105 lokasi; dan pemetaan hidrogeologi sebanyak 25 lembar.

Di bidang pertambangan mineral dan batubara sasaran yang hendak dicapai pada akhir Repelita VI, terutama, adalah produksi batubara mencapai 71 juta ton, produksi timah 40,3 ribu ton, produksi bijih nikel 2.750 ribu ton, produksi bauksit 1 juta ton, produksi tembaga 1.761 ribu ton, produksi emas 70.600 kilogram dan Perak 143.000 kilogram. Di bidang minyak bumi, gas bumi, dan panas bumi sasarannya dalam Repelita VI, antara lain, adalah produksi minyak bumi dan kondensat sebesar 547,5 juta barel, dan produksi gas bumi sebesar 2.960 miliar kaki kubik.

Pertumbuhan sektor pertambangan diharapkan dapat mencapai rata-rata 2,6 persen per tahun selama Repelita VI. Dengan tingkat pertumbuhan ini diharapkan bahwa sektor pertambangan dapat meningkatkan kesempatan kerja dari sekitar 842 ribu orang pada tahun 1993 menjadi 989 ribu orang pada akhir Repelita VI. Dengan demikian, sektor pertambangan diharapkan mampu menciptakan tambahan kesempatan kerja untuk 147 ribu orang selama Repelita VI. Penyerapan tenaga kerja ini terutama diharapkan terjadi dari makin tumbuh dan berkembangnya usaha pertambangan rakyat, termasuk pertambangan skala kecil dalam bentuk koperasi.

Untuk mencapai berbagai sasaran tersebut, kebijaksanaan pembangunan pertambangan pada pokoknya adalah mengembangkan informasi geologi dan sumber daya mineral sebagai pendukung dasar pembangunan pertambangan; memantapkan penyediaan komoditas mineral dan energi melalui peningkatan produksi dan diversifikasi hasil tambang; meningkatkan peranserta rakyat dan melestarikan fungsi lingkungan hidup dalam pembangunan pertambangan; mengembangkan kemampuan sumber daya manusia dan penguasaan teknologi pertambangan guna mendukung peningkatan efisiensi serta produktivitas usaha pertambangan; dan mengembangkan iklim usaha, kemitraan berusaha serta sistem pendukung lainnya bagi peningkatan efektivitas pembangunan pertambangan.

Untuk melaksanakan

kebijaksanaan dan pencapaian berbagai sasaran pembangunan pertambangan, disusun serangkaian program pokok yang terdiri dari program pengembangan geologi dan sumber daya mineral meliputi geologi sumber daya mineral, geologi kelautan, geologi tata lingkungan dan mitigasi bencana alam geologic; program pembangunan pertambangan meliputi pertambangan batubara, pertambangan mineral, pertambangan minyak bumi, gas bumi, dan panas bumi; dan program pengembangan usaha pertambangan rakyat terpadu; serta didukung oleh 
program penunjang yaitu program penelitian dan pengembangan pertambangan; program pendidikan, pelatihan, penyuluhan, dan ketenagakerjaan pertambangan; program pembinaan dan pengelolaan lingkungan hidup; program pengembangan usaha nasional; dan program peningkatan kerjasama internasional.

Pada tahun pertama Repelita VI, peningkatan produksi dan ekspor hasil pertambangan terlihat pada hampir semua jenis mineral. Selain itu, ditemukan sejumlah cadangan baru bahan tambang, baik dalam jumlah besar maupun kecil yang segera dapat dieksploitasi secara ekonomis seperti cadangan tembaga di Irian Jaya dan Nusa Tenggara Barat, gas alam di Arun dan Bontang, beberapa lapangan minyak, cadangan batubara dan mineral logam lainnya serta berbagai bahan galian industri.

Produksi batubara pada tahun 1994/95 mencapai 32.599,5 ribu ton, atau meningkat 14,1 persen dari tahun sebelumnya. Dalam rangka penghematan penggunaan BBM, batubara merupakan sumber energi pengganti minyak bumi yang utama untuk pembangkit energi listrik dan industri semen, serta industri lainnya di dalam negeri. Ekspor batubara juga meningkat dari $18.985,9$ ribu ton pada tahun $1993 / 94$ menjadi $22.080,0$ ribu ton pada tahun 1994/95, atau naik sebesar 16,3 persen. Kemajuan ini telah menempatkan Indonesia sebagai salah satu eksportir batubara terkemuka di dunia. Dalam upaya penganekaragaman konsumsi energi untuk rumah tangga dan industri kecil terutama di daerah perdesaan, pemasyarakatan pemakaian briket batubara sebagai pengganti BBM dan kayu bakar terus diupayakan melalui kegiatan percontohan.

Mengingat peran industri pertambangan dalam rangka pembangunan ekonomi bangsa, maka pemerintah menetapkan Hari Jadi Pertambangan dan Energi, Menteri ESDM menerbitkan Keputusan Menteri Energi dan Sumber Daya Mineral No. 1319 K/73/MEM/2006 tentang Tim Penyusunan Buku Sejarah Pertambangan dan Energi kemudian diperbaharui dengan $\begin{array}{lll}\text { Keputusan } & \text { No. } & 0147\end{array}$ K/73/MEM/200R tanggal 14 Februari 2008.

Penetapan Hari Jadi Pertambangan dan Energi diputuskan dalam Rapat Pimpinan (Rapim) DESDM yang berlangsung pada tanggal 1 Nopember 2007 di Badan Geologi Bandung. diikuti oleh para Pejabat Eselon I dan II DESDM dipimpin oleh Menteri Energi dan Surnber Daya Mineral.

Berdasarkan hasil penetapan tersebut, Menteri Energi dan Sumber Daya Mineral menyampaikan surat kepada Presiden No. 1349/04/ME LS/2008 tanggal 26 Pebruari 2008 mengusulkan Hari Jadi Pertambangan dan Energi untuk ditetapkan dalam Keputusan Presiden. Selanjutnya, dengan Keputusan Presiden Repub1ik Indonesia Nomor 22 tahun 2008 tanggal $27 \quad$ September 2008 ditetapkan Hari Jadi Pertambangan dan Energi adalah tanggal 28 September.

\section{Perkembangan Sejarah Perizinan Pengusahaan Pertambangan}

Pada masa sebelum Belanda datang ke negeri ini, yaitu pada 
zaman Majapahit dan Sriwijaya, bentuk "Perijinan" Pengusahaan Pertambangan yang diberikan oleh Raja atau Pembesar kerajaan lainnya. Kemungkinan diberikan dalam bentuk Lisan saja, sebagaimana yang berlaku secara umum dalam masyarakat hukum adat di negeri ini. Ijin usaha pertambangan yang diberikan oleh para pembesar kerajaan tersesebut, mungkin saja diberikan kepada para penambang tradisional ini secara resmi ditulis pada Pelepah Lontar dalam bahasa Hindu atau jawa Kuno. Namun hingga kini belum pernah ditemukan tentang catatan-catatan resmi tersebut, baik dalam bentuk hikayat dongeng atau cerita-cerita rakyat lainnya. Karena pada masa itu yang berlaku adalah Hukum Adat yang umumnya tidak tertulis. Namun salah satu konsep Hukum Adat yang tidak tertulis ini, yaitu "Maro" atau "Bagi Hasil. Ternyata sampai saat ini masih tetap digunakan sebagai rujukan atau landasan kerjasama pengusahaan Migas dengan Kontraktor Asing, yaitu "Kontrak Production Sharing" (KPS). Bentuk kerjasama bagi hasil ini, yang berakar dari hukum adat Jawa yang bersifat agraris telah diangkat oleh Dr.Ibnu Sutowo, untuk menggantikan konsep dasar Kontrak Karya (KK) Perminyakan yang di adopt dari Kontrak 5-A berdasarkan Pasal 5 A Indische Mijn Wet. Kontrak Karya Perminyakan ini, yang mengikuti Konsep Kontrak 5-A sebagai produk penjajah. Menurut Ibnu Sutowo masih sangat menguntungkan pihak Kontraktor Asing, karena dalam KK ini, manajemen operasi perminyakan masih berada pada pihak kontraktor asing. Sedangkan pada Kontrak Production Sharing ( KPS ), manajemen pengusahaan Migas telah berpindah kepada bangsa Indonesia selaku pemilik bahan galian Migas tersebut.

Dalam

perkembangan selanjutnya ternyata Konsep KPS ini, dapat diterima baik oleh kalangan bisnis perminyakan Internasional.Termasuk para investor asing dari negara-negara besar, seperti: Amerika Serikat, Inggris, Kanada, Perancis, dan Jepang. Kerjasama perminyakan dengan prinsip bagi hasil ini, telah diangkat oleh Ibnu Sutowo selaku Direktur Utama PERMINA, untuk menyempurnakan bentuk kerjasama perminyakan waktu itu (Kontrak Karya), yang mempunyai landasan hukum Pasal 6 ayat (1) UU No.44 Prp.1960. Dimana sesuai Kontrak Karya ini, manajemen kerjasama pengusahaan minyak masih dikuasai oleh 3 perusahaan besar minyak asing. Yaitu: SHELL yang berkontrak dengan PERMIGAN, PT. CALTEX dengan PERTAMINA dan PT. STANCAC dengan PERMINA.

Secara formal konsep bagi hasil ini dikembangkan mulai tahun 1964, yaitu sejak ditanda tanganinya Kontrak Bagi Hasil antara PT PERMINA dengan Refining Associated Ltd. (untuk wilayah daratan). Untuk Kontrak bagi hasil pada kegiatan migas dilepas pantai, dimulai pada tahun 1966 yang ditandai dengan ditandatanganinya Kontrak Bagi Hasil Migas antara PT. PERMINA dengan Indonesia Independent American Petroleum Company (IIAPCO) yang sekarang beralih menjadi PT. MAXUS Oil. Adapun prinsip-prinsip "Kontrak Production Sharing" yang bersifat lebih menguntungkan dari Kontrak Karya Migas antara lain:

a. Manajemen pengusahaan Migas berada ditangan PERTAMINA yang 
bertindak atas nama Pemerintah, selaku pemegang KP Migas

b. Kerjasama didasarkan pada perkembangan produksi (bagi hasil)

c. Resiko pengusahaan ditanggung Kontraktor.

d. Keuntungan diambil dari sisa produksi (dipotong biaya) dengan pembagian $85 \%$ untuk Negara dan $15 \%$ untuk Perusahaan (Kontraktor)

e. Peralatan-peralatan untuk kegiatan operasi Migas yang dibeli Kontraktor setibanya di Indonesia, akan menjadi hak milik Pemerintah.

Kembali pada perkembangan sejarah perijinan pengusahaan pertambangan. Bahwa sejak Belanda datang dan menguasai negeri ini, maka selanjutnya izin-izin pertambangan yang diberikan oleh Sultan-sultan di Sumatera dan Rajaraja di Pulau Jawa dan daerah lain di Indonesia. Selanjutnya diberikan dalam bentuk Konsesi Pertambangan, sesuai Konsep Hukum Perdata Barat sebagaimana diatur dalam Burgirljk Wetboek (BW). Hukum Perdata Barat ini, dibawa oleh Belanda dari negerinya dan diberlakukan di negeri jajahannya ini secara Concordansi. Dengan berkembangnya kegiatan pertambangan termasuk migas di Hindia Belanda ini waktu itu, maka setelah seorang saudagar tembakau bangsa Belanda bernama $J$ Ree Ring menemukan minyak di desa Palimanan Cirebon pada tahun 1897. Pada tahun 1899 Belanda lalu menerbitkan Indische Mijn Wet Stb.1899 No.214, yang mengatur secara khusus tentang perijinan yang bersifat publik dibidang Pertambangan, yang diatur sesuai konsep hukum perdata barat yang tersebut. Dimana semua perijinan yang bersifat publik diberikan dalam bentuk "Konsesi", seperti Konsesi Hutan yang selanjutnya dikenal sebagai Hak Penebangan Hutan atau HPH, Konsesi Perkebunan, sesuai UU Agrarische Wet Stb. 1870 No.55 dan Konsesi Pertambangan baik untuk Pertambangan Umum maupun Minyak dan Gas.

Berdasarkan Indische Mijn Wet Stb.1899 No. 214. Pelaksanaan pemberian Konsesi oleh Pemerintah Hindia Belanda ini, dilakukan dalam rangka menetapkan politik dan kebijakan kolonialnya atas kekayaan alam bahan galian di Indonesia. Undang-undang pertambangan Hindia Belanda ini lahir, dari perkembangan politik pada waktu itu yang dilandasi oleh alam pikiran mereka yang liberalistis dan kapitalis. Kebijakan politik penjajah dibidang pertambangan ini telah melapangkan jalan bagi "Konsesi Pertambangan". Selanjutnya cengkeraman konsesi tersebut terhadap kekayaan nasional bangsa Indonesia ini, berlangsung hingga 15 tahun kita merdeka. Tepatnya hingga tahun 1960, dengan diundangkannya Peraturan Pemerintah Pengganti UndangUndang No.37 tahun 1960, tentang Pertambangan dan Peraturan Pemerintah Pengganti Undangundang No.44 tahun 1960 tentang Migas.

\section{Arti Penting Investasi di Bidang Pertambangan}

Istilah investasi atau penanaman modal banyak digunakan dalam kegiatan bisnis sehari-hari maupun dalam bahasa perundangundangan, istilah investasi banyak digunakan dalam dunia usaha, maka istilah penanaman modal banyak 
digunakan dalam perundangundangan.

Investasi berasal dari bahasa latin, yaitu investire (memakai), sedangkan dalam bahasa Inggris disebut dengan investment. Dalam berbagai kepustakaan hukum ekonomi atau hukum bisnis, terminologi penanaman modal dapat berarti penanaman modal yang dilakukan secara langsung oleh investor lokal (Domestic investor), investor asing (Foreign Direct Investment) dan penanaman modal yang dilakukan secara tidak langsung oleh pihak asing (Foreign Indirect Investment) melalui pembelian efek lewat Lembaga Pasar Modal (Capital Market).

Dalam perhitungan pendapatan nasional dan satstistik, investasi meliputi hal yang lebih luas lagi. Menurut Sukirno (1994 : 91), dalam perhitungan pendapatan nasional, investasi meliputi hal-hal: "Seluruh nilai pembelian pengusaha atas barang-barang modal dan pembelanjaan untuk mendirikan industri-industri, pengeluaran masyarakat untuk mendirikan rumah-rumah dan tempat tinggal, pertambahan dalam nilai stok barang-barang berupa bahan mentah, barang yang belum selesai di proses dan barang jadi".

Dalam kaitannya dengan perusahaan dimana perusahan melakukan investasi guna mendapatkan profit yang sebesarbesarnya, di mana dana investasi tersebut salah satunya bersumber dari dana masyarakat yang di tabung pada lembaga-lembaga keuangan, maka Deliarnov mengemukakan bahwa "investasi merupakan pengeluaran perusahaan secara keseluruhan yang mencakup pengeluaran untuk membeli bahan baku/ material, mesin-mesin dan peralatan pabrik serta semua modal lain yang di perlukan dalam proses produksi. Pengeluaran untuk keperluan bangunan kantor, pabrik tempat tinggal karyawan dan bangunan kontruksi lainnya. Perubahan nilai stok atau barang cadangan sebagai akibat dari perubahan jumlah dan harga".

Investasi merupakan salah satu sektor pendukung kemajuan ekonomi di setiap negara. Semua negara memiliki kekurangan dan kelebihan untuk saling mengisi antara satu negara dengan negara lain. Untuk menutupi kekurangan serta memajukan perekonomian suatu negara diantaranya melalui jalan investasi, yang merupakan salah satu jalur hubungan negara baik secara bilateral maupun multilateral. Sebab investasi akan menambah income negara melalui pemasukan pajak dan mengurangi pengangguran.

Pertimbangan utama suatu negara mengoptimalkan peran investasi baik asing maupun dalam negeri adalah untuk merubah potensi ekonomi menjadi kekuatan ekonomi riil dalam rangka meningkatkan pertumbuhan ekonomi (economic growth). Peran investasi tidak hanya sebagai alternatif terbaik sumber pembiayaan pembangunan apabila dibandingkan dengan pinjaman luar negeri, tetapi juga sangat penting sebagai alat untuk mengintegrasikan ekonomi suatu negara kedalam ekonomi global. Di samping itu, investasi dapat menghasilkan multiplayer effect terhadap pembangunan ekonomi nasional, karena kegiatan investasi tidak saja mentransfer modal dan barang, tetapi juga mentransfer ilmu pengetahuan 
dan modal sumber daya manusia, memperluas lapangan kerja, mengembangkan industri substitusi impor untuk menghemat devisa, mendorong ekspor non migas untuk menghasilkan devisa, alih teknologi, membangun prasarana, dan mengembangkan daerah tertinggal.

Oleh karena itu banyak negara, tidak terkecuali Indonesia, yang menjadikan kegiatan investasi sebagai bagian dari penyelenggaraan perekonomian nasionalnya. Target pertumbuhan ekonomi sebesar 7.9\% hingga 2009 yang ditetapkan oleh Pemerintah Indonesia menjadikan peran investasi menjadi kian penting, mengingat tingkat konsumsi dalam negeri saat ini tidak akan mampu menciptakan lapangan kerja yang cukup. Hal ini jelas memberikan tekanan kepada Indonesia untuk menarik lebih banyak investasi baru, khususnya dari luar negeri, guna menutup kekurangan (Mahmul Siregar).

Berdasarkan Undang-undang Nomor 25 tahun 2007 tentang Penanaman modal memberikan faedah bahwa Indonesia menerima kegiatan investasi dalam bentuk penanaman modal asing maupun dalam negeri. Dalam pertimbangan (konsiderans) huruf c, bahwa untuk mempercepat pertumbuhan ekonomi nasional dan mewujudkan kedaulatan politik dan ekonomi Indonesia diperlukan peningkatan penanaman modal untuk pengelolaan potensi ekonomi menjadi kekuatan ekonomi riil dengan menggunakan modal yang berasal, dari dalam negeri maupun dari luar negeri. Sebagian asas penanaman modal yang penting dalam menunjukkan kegiatan investasi yaitu pasal 3 huruf j keseimbangan kemajuan dan kesatuan ekonomi nasional.

Masuknya modal asing di suatu negara, terutama negara-negara berkembang khususnya di Indonesia akan memberikan dampak positif bagi negara penerima modal, seperti mendorong tumbuhnya bisnis, adanya supply teknologi dari investor baik dalam bentuk proses produksi maupun permesinan, dan menciptakan lapangan pekerjaan.

Secara rinci, penanaman modal asing dapat memberikan keuntungan cukup besar terhadap perekonomian nasional, misalnya dapat berupa (Hafnifiaty Shinta;2009):

a. Menciptakan lapangan kerja bagi penduduk tuan rumah, sehingga mereka dapat meningkatkan penghasilan dan standar hidup.

b. Menciptakan kesempatan penanaman modal bagi penduduk tuan rumah, sehingga mereka dapat berbagi dari pendapatan perusahaan-perusahaan baru.

c. Meningkatkan ekspor dari negara tujuan rumah, sehingga mendatangkan penghasilan tambahan dari luar yang dapat dipergunakan untuk kepentingan penduduknya.

d. Melaksanakan pengalihan pelatihan teknis dan pengetahuan, yang mana dapat digunakan oleh penduduk untuk mengembangkan perusahaan dan industri lain.

e. Memperluas potensi keswasembadaan pangan tuan rumah dengan memproduksi barang setempat untuk menggantikan barang impor.

f. Menghasilkan pendapatan pajak tambahan yang dapat digunakan untuk berbagai keperluan, demi kepentingan penduduk dari negara tuan rumah. 
g. Membuat sumber daya tuan rumah baik sumber daya alam maupun sumber daya manusia lebih baik pemanfatannya dari semula.

Sehubungan dengan kegiatan investasi, maka investor harus memenuhi syarat atau ketentuan yang diatur dalam peraturan perundang-undangan, sehingga dapat memudahkannya dalam mengajukan izin untuk melakukan investasi. Menurut Salim HS (Budi Sutrisno;2008) dalam pendapatnya yang menyatakan Hukum Investasi mengatur hubungan investor dengan penerima modal. Dalam keadaan ini maka status investor dapat dibagi menjadi dua investor asing dan investor domestik. Investor asing merupakan penanam modal yang berasal dari luar negeri sedangkan investor domestik merupakan penanam modal yang berasal dari dalam negeri. Bidang usaha merupakan bidang kegiatan yang diperkenankan atau diperbolehkan untuk berinvestasi. Prosedur dan syarat-syarat merupakan tata cara yang harus dipenuhi oleh investor dalam menanamkan investasinya.

Untuk itu, Negara Indonesia dalam Keputusan Presiden No. 117 tahun 1999 tentang Tata Cara Penanaman Modal yang mengatur metode dan langkah setiap investor yang akan melakukan investasi di daerah, sedangkan dalam Keputusan Presiden No. 29 tahun 2004 tentang Penyelenggaraan Penanaman Modal Dalam Rangka Penanaman Modal Asing dan Penanaman Modal Dalam Negeri Melalui Sistem Pelayanan Satu Atap.

Indonesia yang kaya akan sumber daya sangat berpotensi untuk mengembangkan sektor pertambangan sebagai salah satu penggerak laju pertumbuhan ekonomi bangsa. Namun Indonesia juga tidak lepas dari berbagai kekurangan, tidak mampu mencukupi kebutuhan sendiri baik dari segi fisik dan non fisik serta kebutuhan yang bersifat konsumtif maupun non konsumtif. Misalnya pengadaan teknologi canggih untuk mengolah berbagai kekayaan alam yang dimiliki. Maka sebuah keniscayaan bagi Indonesia untuk membangun investasi di bidang pertambangan dengan jalan menarik negara-negara lain masuk ke Indonesia untuk berivestasi mengelola mineral yang terkandung di bumi Indonesia.

Indonesia dituntut untuk bergerak cepat dengan stabilitas penduduk yang semakin kompleks, salah satu penyebabnya adalah pengangguran yang merajalela. Permasalahan ini terjadi karena kebutuhan masyarakat yang kian meningkat, sehingga menimbulkan peningkatan kebutuhan akan sarana, energi dan bahan-bahan mentah yang pada akhirnya menambah tekanan terhadap lingkungan dan sumbersumber kehidupan. Hal ini memberikan tantangan bagi institusi pemerintahan dan hukum untuk merancang strategi dan membuat aturan yang tepat untuk menarik investor. Indonesia dengan sumber daya mineral dan tambang yang melimpah memerlukan sumber daya manusia dan sumber dana (investasi) untuk membangun perekonomian dan mengelola sumber daya alam yang ada.

Investasi di bidang pertambangan sangat berperan penting dalam usaha percepatan perbaikan ekonomi bangsa, selain untuk menutupi kekurangan dana pembangunan, investasi ini juga akan 
memacu persaingan usaha bagi kalangan pengusaha domestik. Dengan demikian, arti modal asing yang ditanamkan dalam industri pertambangan bagi pembangunan ekonomi negara-negara berkembang, termasuk Indonesia pada dasarnya adalah untuk meningkatkan perekonomian nasional dan modernisasi struktur ekonomi nasional disamping untuk mengelola kekayaan alam yang dimiliki. Dengan meningkatnya pertumbuhan ekonomi nasional, tujuan-tujuan lain yang ingin dicapai seperti mengembangkan industri substitusi import untuk menghemat devisa, mendorong eksport nonmigas untuk menghasilkan devisa, alih teknologi, membangun prasarana, dan mengembangkan daerah tertinggal dapat terlaksana.

Sebelum calon investor menanamkan modalnya di suatu negara, ada beberapa hal yang yang menjadi perhatian negara calon investor. Beberapa hal ini seringkali menjadi perhatian bagi investor agar dapat meminimalisir resiko dalam berinvestasi, antara lain:

a. Keamanan investasi yang sering berkaitan dengan stabilitas politik di suatu negara

b. Bahaya tindakan nasionalisasi dan berkaitan dengan ganti kerugian

c. Repartriasi keuntungan dan modal dan konvertibilitas mata uang

d. Penghindaran pajak berganda

e. Masuk dan tinggalnya staff atau ahli yang diperlukan

f. Penyelesaian sengketa

g. Perlakuan sama terhadap investor asing dan tidak adanya pembedaan dari investor domestik

h. Insentif untuk penanaman modal

i. Transparency, yaitu kejelasan mengenai peraturan perundangan, prosedur administrasi yang berlaku, serta kebijakan investasi

j. Kepastian hukum, termasuk enforcement putusan-putusan pengadilan.

Ada beberapa hal yang perlu diperhatikan dalam menarik masuknya investor dan yang paling penting adalah menciptakan iklim investasi yang kondusif. Iklim investasi ini berupa kebijakan dan lingkungan, baik yang sedang berlangsung maupun yang akan datang, dimana kebijakan dan lingkungan ini dapat mempengaruhi tingkat pengembalian dan resiko investasi. Menurut Erman Rajagukguk(2007; 13) suatu negara dapat dikatakan memiliki iklim investasi yang kondusif bila memenuhi syarat-syarat; pertama, ada economic opportunity (investasi mampu memberikan keuntungan ekonomis bagi investor); kedua, political stability (investasi akan sangat dipengaruhi stabilitas politik); ketiga, legal certainty atau kepastian hukum.

Dari ketiga syarat tersebut faktor kepastian hukum (legal certainty) merupakan problem tersendiri bagi Indonesia. Kepastian hukum ini meliputi perundangundangan yang dalam banyak hal tidak jelas bahkan bertentangan, dan juga mengenai pelaksanaan putusanputusan pengadilan (Camelia Malik;2007). Termasuk pula di dalamnya komitmen dan konsistensi pemerintah dalam menegakkan peraturan perundang-undangan. Untuk mewujudkan sistem hukum yang mampu mendukung iklim investasi diperlukan aturan yang jelas mulai dari izin untuk usaha sampai dengan biaya-biaya yang harus dikeluarkan untuk mengoperasikan 
perusahaan. Untuk mencapai kondisi ini yang diperlukan adalah adanya penegakan supremasi hukum (rule of law).

\section{Kepastian Hukum Investasi di Sektor Pertambangan}

Negara Indonesia adalah Negara berkembang yang memiliki tujuan dan arah pembangunan nasional yaitu mewujudkan suatu mayarakat adil dan makmur. Masyarakat yang adil dan makmur dapat diwujudkan melalui pembangunan di berbagai bidang diantaranya ekonomi. Sektor perekonomian di daerah umumnya berada pada sektor pertanian, perikanan, kehutanan, peternakan dan pertambangan. Dari sektorsektor ekonomi tersebut, sektor pertambangan sedang menjadi primadona bagai para investor untuk menginvestasikan modalnya. Keberhasilan pembangunan perekonomian di daerah melalui industri pertambangan tidaklah mudah, selain memerlukan dukungan dari berbagai pihak terkait, juga membutuhkan modal yang besar

Keberhasilan dalam bidang perekonomian ini dapat dicapai dengan beberapa cara. Diantaranya yaitu menyetujui adanya investasi daerah. Perkembangan investasi di Indonesia merupakan salah satu indikator kemajuan pertumbuhan ekonomi di Indonesia. Investasi yang dilakukan secara tepat dapat mendukung tercapainya peningkatan kesejahteraan masyarakat Indonesia. Faktor yang mempengaruhi pelaksanaan investasi di Indonesia yaitu dengan pemberlakuan otonomi daerah.

Investasi merupakan salah satu instrumen dalam sistem perekonomian suatu bangsa yang sangat penting, tidak mengherankan jika di negara maju maupun negara Indonesia berusaha secara optimal untuk menjadi tujuan investasi guna menggerakkan roda perekonomian yang berhubungan langsung dengan sistem produksi, kegiatan perdagangan dan ekspor serta kegiatan ekonomi masyarakat pada umumnya. Ruang lingkup ini tidaklah berlebihan jika dikemukakan bahwa kehadiran investasi merupakan suatu hal yang signifikan dalam pembangunan nasional atau tepatnya dalam menggerakkan roda perekonomian yang dilakukan pemerintah.

Berdasarkan Undang-undang Nomor 25 tahun 2007 tentang Penanaman Modal memberikan faedah bahwa Indonesia menerima kegiatan investasi dalam bentuk penanaman modal asing maupun dalam negeri. Dalam pertimbangan (konsiderans) huruf c, bahwa untuk mempercepat pertumbuhan ekonomi nasional dan mewujudkan kedaulatan politik dan ekonomi Indonesia diperlukan peningkatan penanaman modal untuk pengelolaan potensi ekonomi menjadi kekuatan ekonomi riil dengan menggunakan modal yang berasal, dari dalam negeri maupun dari luar negeri. Sebagian asas penanaman modal yang penting dalam menunjukkan kegiatan investasi yaitu pasal 3 huruf $j$ keseimbangan kemajuan dan kesatuan ekonomi nasional.

Iklim investasi di Indonesia yang masih belum kondusif menimbulkan kekhawtirankekhawatiran bagi para investor. Apalagi investasi di bidang pertambangan yang memerlukan dana besar dengan risiko yang relatif tinggi. Para investor merasa 
khawatir akan banyaknya risiko yang akan ditemui. Kondisi ini dipengaruhi oleh situasi hukum dan politik Indonesian yang tidak menentu.

Menurut Blacklaw Dictionary (1982: 847), hukum pertambangan adalah: "the act appropriating a mining claim (parcel of land containing precious metal its soil or rock) according to certain established rule". Artinya ketentuan yang khusus yang mengatur hak menambang (bagian dari tanah yang mengandung logam berharga di dalam tanah atau bebatuan) menurut aturan-aturan yang telah ditetapkan.

Sementara itu, Salim HS mendefinisikan Hukum pertambangan adalah: "keseluruhan kaidah hukum yang mengatur kewenangan negara dalam pengelolaan bahan galian (tambang) dan mengatur hubungan hukum antara negara dengan orang dan atau badan hukum dalam pengelolaan dan pemanfaatan bahan galian (tambang)".

Kaidah hukum dalam hukum pertambangan dibedakan menjadi dua macam, yaitu kaidah hukum pertambangan tertulis dan tidak tertulis. Hukum pertambangan tertulis merupakan kaidah-kaidah hukum yang terdapat di dalam peraturan perundang-undangan, traktat dan yurisprudensi. Hukum pertambangan tidak tertulis merupakan ketentuan-ketentuan hukum yang hidup dan berkembang dalam masyarakat. Bentuknya tidak tertulis dan sifatnya lokal, artinya hanya berlaku dalam masyarakat setempat.

Dalam kegiatan investasi di sektor pertambangan, kepastian hukum merupakan faktor utama dalam menentukan sukses atau tidaknya kegiatan investasi tersebut. Investor yang menanamkan modal di negara-negara berkembang seperti Indonesia umumnya menuntut kesiapan negara tersebut dari aspek keamanan dan kepastian hukum dalam berinvestasi. Namun, hal ini belum sepenuhnya terwujud dalam industri pertambangan di dalam negeri. Manajemen buruk pemerintah dalam mengelola sektor pertambangan secara tidak langsung telah mengakibatkan kerugian negara secara materil. Artinya, potensi industri pertambangan dimana merupakan salah satu penyumbang bagi perkembangan perekonomian di Indonesia, tidak lagi secara maksimal memberikan kontribusi terhadap pendapatan negara dan memajukan perekonomian di daerah.

Pada dasarnya, permasalahan tersebut sudah lama menjadi kendala utama dalam bidang pertambangan di Indonesia. Namun, pemerintah tidak segera menyelesaikannya yang menyebabkan permasalahan ini semakin berlarut-larut. Padahal melalui datangnya investor dalam mengelola sumber daya alam yang melimpah dapat dimanfaatkan oleh pemerintah Indonesia untuk pembiayaan bangsa.

Ada dua hambatan atau kendala yang dihadapi dalam menggerakkan investasi secara keseluruhan di Indonesia, sebagaimana diinventarisasi oleh BKPM (Badan Koordinasi Penanaman Modal), yaitu kendala internal dan eksternal. Kendala internal, meliputi:
a. Kesulitan perusahaan mendapatkan lahan atau lokasi proyek yang sesuai
b. Kesulitan memproleh bahan baku
c. Kesulitan dana/ pembiayaan
d. Kesulitan pemasaran 
e. Adanya sengketa perselisihan di antara pemegang saham.

Sementara itu, yang menjadi kendala eksternal, meliputi:

a. Faktor lingkungan bisnis, baik nasional, regional dan global yang tidak mendukung serta kurang menariknya insentif atau fasilitas investasi yang diberikan pemerintah

b. Masalah hukum

c. Keamanan, maupun stabilitas politik yang merupakan faktor eksternal ternyata menjadi faktor penting bagi investor dalam menanamkan modal di Indonesia

d. Adanya peraturan daerah, keputusan menteri, undangundang yang turut mendistorsi kegiatan penanaman modal

Selain hambatan-hambatan tersebut, terdapat hambatan lain yang lebih krusial yaitu perlindungan dan kepastian hukum terhadap investasi, konsistensi perundangundangan, maupun kebijakan industri pertambangan di Indonesia tergolong paling banyak disoroti. Banyak investor asing menilai bahwa investasi di Indonesia sulit dijamin keamanan serta perlindungan hukumnya dikarenakan kepastian hukumnya yang dinilai tidak stabil dan konsisten melindungi para investor. Pemerintah dianggap lemah dalam hal ini. Hasil survei Bank Dunia terhadap 155 negara menunjukkan bahwa iklim investasi di Indonesia dinilai sebagai salah satu yang terburuk. Iklim investasi yang dimaksudkan mencakup kepastian hukum, stabilitas ekonomi makro, sistem dan ketersediaan infrastruktur (listrik, jalan, pelabuhan, telekomunikasi, dsb).

Sehubungan dengan ini, koordinasi yang baik sangat diperlukan antara pemerintah pusat dan pemerintah Provinsi serta pemerintah daerah. Koordinasi tersebut dijalankan dengan kewenangan otonomi daerah. Dalam pengembangan potensi daerah, investasi merupakan bagian integral. Oleh karena itu potensi daerah harus dapat menjadi sasaran bagi pengelolaan pendapatan asli daerah. Sayangnya, dalam pelaksanaan wewenang otonomi daerah ini dijadikan "kesempatan" oleh Kepala Daerah atau oknum pejabat daerah untuk memperkaya dirinya, tentunya hal ini dapat menciptakan ketidakpastian investasi di daerah. Sebagai contoh adanya Peraturan Daerah (perda) tentang retribusi yang dikenakan kepada investor yang menanamkan modalnya di daerah. Padahal dalam kontrak yang ditandatangani oleh pemerintah pusat dan investor, pungutan tersebut sudah termasuk di dalamnya. Hal itu menyebabkan banyak terjadi pungutan berganda. Hal ini banyak ditemukan dalam surat-surat resmi kepala daerah atau surat resmi dari dinas pertambangan terkait. Tentunya peraturan daerah yang dikaitkan dengan retribusi dirasakan menghambat investasi, yang berdampak pada menurunnya investasi baru di sektor pertambangan.

Selain itu, keamanan yang kondusif juga sangat mempengaruhi iklim investasi. Meskipun gangguan keamanan ataupun gangguan sosial itu terjadi di beberapa daerah tertentu di Indonesia, namun para investor khususnya investor asing menganggap kondisi tersebut berlaku di seluruh wilayah Indonesia. Gangguan keamanan dimaksud antara lain: unjuk rasa, 
demo, pemogokan, dan lainnya yang dilakukan buruh sebagai akibat provokasi dari beberapa oknum terkadang berbuntut pengerusakan terhadap fasilitas-fasilitas perusahaan. Berdasarkan fakta-fakta tersebut dapat dikatakan bahwa iklim investasi di Indonesia tidak lagi kondusif karena stabilitas sosial dan politik serta jaminan keamanan dan penegakan hukum di dalam negeri masih rawan. Sebagai dampaknya hal ini menyebabkan berbagai permasalahan yang kemudian mengakibatkan kurangnya minat investor untuk menanamkan modalnya. Bahkan investor yang telah memiliki usaha di Indonesia menutup dan memindahkan usahanya ke negara lain yang lebih aman untuk berinvestasi.

Melihat semua fenomena tersebut kemudian timbul rasa khawatir melihat tumpang tindih dan ketidaksinkronan peraturan perundang-undangan yang ada. Kini, semakin banyak peraturan yang memuat ancaman pidana bukan saja terhadap orang pribadi, tetapi juga terhadap perusahaan sebagai badan hukum.

Bermula dari Undang-undang Lingkungan Hidup, kini ancaman pidana berkembang ke hukum bisnis (investasi). Ironisnya, ancaman yang dikenakan semakin beragam padahal semula sanksinya adalah denda. Pembuatan norma ancaman pidana semakin tak terkendali lagi.

Menurut Prof Nindyo Pramono (2014), isu besar yang menjadi masalah adalah tidak jelasnya tolak ukur penerapan ancaman pidana atau normanya sangat umum dan elastis, sehingga bisa diterjemahkan ke arah mana saja. Ketidak jelasan tolok ukurini 'merugikan negara' dalam konteks tindak pidana korupsi atau bidang lain. Keetidakjelasan akan berdampak pada banyak orang.

Semakin banyak Undangundang yang memuat tanggung jawab pidana korporasi. Di satu sisi, pengaturan demikian membawa perubahan penting dan positif hukum pidana. Tetapi di sisi lain bisa berdampak buruk jika tidak ada tolok ukur yang jelas dan tegas. Pemilik saham atau korporasi akan berpikir dua kali menanamkan investasi jika terlalu banyak ancaman yang bisa menjerat perusahaan.

Dalam dunia bisnis dikenal asas business judgement rule. Business Judgement Rule (BJR) adalah salah satu dari beberapa doktrin hukum perusahaan yang harus dijalankan oleh direksi Perseroan Terbatas guna memenuhi fiduciary duty. BJR menganut prinsip bahwa direksi suatu perusahaan tidak bertanggung jawab atas kerugian yang timbul dari suatu tindakan pengambilan keputusan, sepanjang keputusan tersebut telah didasarkan pada itikad baik dan sepenuhnya untuk kepentingan perusahaan.

Menurut Nindyo Pramono (2014), BJR dipergunakan untuk melindungi direksi dan jajarannya dari setiap kebijakan atau keputusan bisnis atau transaksi bisnis yang dilakukan untuk kepentingan perseroan sesuai dengan maksud dan tujuan perseroan, dengan catatan: selama kebijakan atau keputusan bisnis atau transaksi bisnis tersebut dilaksanakan sejalan dengan wewenangnya dan dengan mengedepankan prinsip kehatihatian (prudent), itikad baik (goodfaith), dan penuh tanggung jawab (accountable/ responsible). 
Kepastian hukum dan keamamanan dapat diwujudkan bila investasi mendapat dukungan dari seluruh elemen bangsa, pemerintah (birokrasi) dapat memulainya dengan mempermudah proses perizinan dan tidak mencari-cari penafsiran sendiri untuk memperoleh keuntungan pribadi serta di dukung oleh masyarakat. Dukungan seperti ini secara langsung akan membuat investasi meningkat dam membuat investasi itu sendiri menjadi tulang punggung pembangunan ekonomi yang memberikan kesejahteraan dan kemakmuran bagi masyarakat Indonesia.

\section{Simpulan}

Dari pembahasan pada bab sebelumnya maka dapat diambil kesimpulan sebagai berikut:

1. Kegiatan usaha pertambangan di Indonesia sudah dimulai sejak zaman keemasan kerajaan Hindu Sriwijaya dan masa kejayaan Majapahit, hal ini terlihat dari jejak peninggalannya kedua keraajn tersebut.

2. Pada zaman Majapahit dan Sriwijaya, bentuk "Perijinan" Pengusahaan Pertambangan yang diberikan oleh Raja atau Pembesar kerajaan lainnya. Kemungkinan diberikan dalam bentuk Lisan saja, sebagaimana yang berlaku secara umum dalam masyarakat hukum adat di negeri ini.

3. Sering perkembangannya, untuk mendapatkan perizinan pengusahaan pertambangan dirasa sangat sulit dan mrlalui prosedur yang berbelit-belit serta tidak adanya kejelasan tentang biaya yang harus dileuarkan untuk memperoleh perizinan pengusahaan pertambangan tersebut.

4. Indonesia memang memiliki prospek bisnis pertambangan yang cukup menarik. Namun, perkembangan bisnis pertambangan Indonesia di masa depan nampaknya akan banyak ditentukan oleh kebijakan di industri pertambangan.

5. Lahirnya Undang-undang Otonomi Daerah tidak dimanfaatkan secara meksimal oleh Kepala Daerah atau stakesholders terkait untuk memajukan perekonomian di daerahnya dengan mengundang investor baik dalam maupun luar negeri. Sayangnya, Undang-undang otonomi daerah tersebut dijadikan ajang memperoleh kekayaan pribadi maupun kelompoknya dengan cara menerbitkan Peraturan Daerah (Perda) yang bertentangan dengan Kebijakan Pemerintah Pusat.

6. Banyak faktor yang mempengaruhi ketidakpastian hukum dalam berinvestasi khususnya pada sektor pertambangan, antara lain: adanya peraturan daerah yang tidak mendukung iklim investasi, kebijakan UMR serta keamaan yang tidak kondusif.

\section{Daftar Pustaka \\ Buku}

Aulia Zul Thirafi, Muhammad. 2012. Pengaruh Pertumbuhan Ekonomi, Ketersediaan Tenaga Kerja, Infrastruktur dan Kepadatan Penduduk Terhadap Penanaman Modal Asing di Kabupaten Kendal. Semarang: Universitas Negeri Semarang.

Camelia Malik. Jaminan Kepastian Hukum Dalam Kegiatan Penanaman Modal di Indonesia. 
Artikel pada Jurnal Hukum Bisnis, Volume 26, Nomor 4, Tahun 2007.

Erman Rajagukguk, 2007. Hukum Investasi di Indonesia : Anatomi Undang-undang No.25 Tahun 2007 Tentang Penanaman Modal. Jakarta: Fakultas Hukum Universitas Al-Azhar Indonesia.

Ferry Aries Suranta, 2012. Penggunanaan Lahan Hak Ulayat dalam Investasi Sumber Daya Alam Pertambangan Di Indonesia. Jakarta: Gramata Publishing

Hayati Tri, 2012. Perizinan

Pertambangan di Era Reformasi Pemerintahan Daerah Studi Tentang Perizinan Pertambangan Timah di Pulau Bangka. Depok: Badan Penerbit FHUI.

I.B.R Supancara, 2010. Ikhtisari ketentuan Penanaman Modal, Nasional Legal Reform Program. Jakarta: PT Gramedia.

Kamaruddin Ahmad, 1996. DasarDasar Manajemen Investasi. Jakarta: Rineka Cipta.

Kertapraja Koswara, 2010. Pemerintahan Daerah. Jakarta: Inner. Majid, M. Khairin, 2013. Analisis Pengaruh Utang Luar Negeri (ULN) dan Penanaman Modal Asing (PMA) Terhadap Pertumbuhan Ekonomi Indonesia Tahun 1986-2011. Malang: Universitas Brawijaya.

Metger, Miller and Bares, Philips, 1989. Business Law and the Regulatory Environment: Concepts ad Cases. Seventh Edition. BIP, Irwin.

Nusantara, Agung dkk, 2001. Analisis Peranan Modal Asing Terhadap Pertumbuhan Ekonomi
Indonesia. Semarang: STIE

Stikubang Semarang.

Rai Widjaya, 2005. Penanaman Modal. Jakarta: Pradnya Paramita.

Rajagukguk, Erman, 2007 Hukum Investasi Di Indonesia: Anatomi Undang-UndangNo.25 Tahun 2007 Tentang Penanaman Modal, Cet. ke-1, (Jakarta: Fakultas Hukum Universitas AlAzhar Indonesia).

Richard Burton Simatupang, 2007. Aspek Hukum Dalam Bisnis. Jakarta: Rineka.

Ridwan HR, 2003. Hukum Administrasi Negara. Yogyakarta: UII Press.

Pangaribuan simanjuntak, SH., Prof Emmy. 1994. Perusahaan Kelompok. Yogyakarta: Seksi Hukum Dagang Fakultas Hukum Universitas Gadjah Mada

Pramono, Nindyo, 1997. Sertifikasi Saham PT Go Public dan Hukum Pasar Modal di Indonesia. Bandung: PT. Citra Aditya Bakti. Salim HS, 2008. Hukum Investasi di Indonesia. Jakarta: Rajawali Pers.

Salim HS, 2010. Hukum Pertambangan di Indonesia. Jakarta: Rajawali Pers.

Saleng Abrar, 2004. Hukum Pertambangan. Yogyakarta: UII Press

Scheeman, Angela, 1997. The Law of Corporations, Partnerships, and Sole Proprietorship. Albany: Delmar Publisher.

Sentosa Sembiring, 2007. Hukum Investasi : Pembahasan Dengan Undang-undang Nomor 25 Tahun $2007 \quad$ Tentang Penanaman Modal. Bandung: Nuansa Aulia, Bandung.

Setyowati, Eni dkk. 2008. Kualitas investasi asing terhadap pertumbuhan ekonomi, vol. 9 
no.1, hal. 69-88. Surakarta : Universitas Muhammadiyah Surakarta.

S.F.Marbun, 2002. Dimensi-dimensi Pemikiran Hukum Administrasi Negara. Yogyakarta: UII Pres. Simatupang Richard, 2007. Aspek Hukum Dalam Bisnis. Jakarta: Rineka Cipta. Sudikno Mertokusumo, 1988. Mengenal Hukum Suatu Pengantar, Edisi Ke II. Yogyakarta: Liberty.

Sutedi Adrian. 2011. Hukum Pertambangan. Jakarta: Sinar Grafika. Supancara, 2010. Ikhtisari ketentuan Penanaman Modal, Nasional Legal Reform Program,. Jakarta: PT Gramedia.

Zaenuddin, Muhammad. 2009. Analisis faktor-faktor yang mempengaruhi Investasi PMS di Batam, Volume 2 nomor 2 hal. 156-166. Batam : Politeknik Batam.

Wild, Susan Ellis, 2006. Webster's New World Law Dictionary. Canada: Wiley Publishing.

\section{Sumber Jurnal :}

Bhasin Balbir and Venkataramany Sivakumar. Paper: Mining Law and Policy: Replacing the 'Contract of Work' System in Indonesia. Bhasin Balbir is an Associate Professor of International Business, Welch College of Business, Sacred Heart University. Venkataramany Sivakumar is an Associate Professor of Finance and International Business, Dauch College of Business and Economics, Ashland University

Bell F. Gary, copyright 2001. The New Indonesian Laws Relating to Regional Autonomy: Good Intentions, Confusing Laws.
Published by Asian-Pacific Law \& Journal (APL\&PJ), University of Hawaii.

J. M. Otto. Mineral policy, legislation and regulation. A series of papers prepared for the United Nations Conference on Trade and Development (UNCTAD). Colorado School of Mines, USA. Published by UNCTAD.

Karim A. Mirza and Mills Karen, 2003. Indonesian Legal Framework in the Oil, Gas, Energy, and Mining Sectors; Including Dispute Resolution. Jakarta: KarimSyah Law Firm

Malik Camelia, 2007. Jaminan Kepastian Hukum dalam Kegiatan Penanaman Modal di Indonesia. Artikel Pada Jurnal Hukum Bisnis, Volume 26, Nomor 4.

Pramono, Nindyo, 1997. Kesiapan Instrumen Hukum Pasar Modal Indonesia Dalam Menghadapi Pasar Bebas, Makalah, Tidak dipublikasikan, Yogyakarta.

Shinta Hafnifiaty, 2009. Arti Penting Kepastian Hukum Dalam Investasi Bidang Pertambangan di Indonesia. Skripsi. Fakultas Hukum, Universitas Islam Indonesia.

Siregar Mahmud, 2008. Kepastian Hukum Dalam Transaksi Bisnis Internasional dan Implikasinya Terhadap Kegiatan Investasi di Indonesia. Jurnal Hukum Bisnis. Fakultas Hukum, Universitas Sumatera Utara.

Soedarjono, Jogi Tjiptadi, 2000. Laporan Akhir Penyusunan Komplikasi Hukum Bidang Pemanfaatan Energy. Jakarta: Badan Pembinaan Hukum Nasional. 
Syahrir Rezki and Friend, 2013. The Future of Indonesian Mining Activities after the Implementation of Law Number 4 of 2009 Concerning Mineral and Coal Mining (The New Mining Law). The IMRE Journal Volume 7 (1) 2013.

Vivoda Vlado and Terry O"Callaghan. Paper: Regimes, Mining Investment and Regulatory Risk in the Asia-Pacific Region: Comparative Evaluation and Policy Implications. Vivoda Vlado is a Research Fellow, School of Communication, International Studies and Languages, University of South Australia and Terry O"Callaghan is an Associate Professor, School of Communication, International Studies and Languages, University of South Australia.

\section{Sumber Peraturan Perundangan:}

Undang-undang Dasar tahun 1945.

Undang-undang No. 22 tahun 1999 tentang Pemerintah Daerah.

Undang-undang No. 25 tahun 1999 tentang Perimbangan Keuangan antara Pemerintah Pusat dan Daerah.

Undang-Undang Nomor 25 Tahun 2007 Tentang Penanaman Modal Keputusan.

Undang-undang Nomor 32 tahun 2004 tentang Pemerintahan Daerah.

Undang-Undang Nomor 4 Tahun 2009 tentang Pertambangan Mineral dan Batubara.

Keputusan Presiden No. 117 Tahun 1999 tentang Tata Cara Penanaman Modal.

Keputusan Presiden No. 29 tahun 2004 tentang Penyelenggaraan Penanaman Modal Dalam Rangka Penanaman Modal Asing dan Penanaman Modal Dalam Negeri Melalui Sistem Satu Atap

\section{Sumber Internet:}

http://www.hukumonline.com http://www.fh.unsri.ac.id http://www.investasibisnis.weebly.c om

http://www.hukumpertambangan.w ordpress.com http://www.ramdri.com http://www.repository.usu.ac.id http://www.mineraltambang.com http://www.esdm.go.id http://www.bappenas.go.id 